\title{
EMPLOYMENT RELATION: COMMON-LAW CONCEPT AND LEGISLATIVE DEFINITION
}

\author{
BENJAMIN S. ASIA $\dagger$
}

ONE of the crucial problems faced in unemployment compensation legislation was the drafting of provisions which would insure coverage of those intended to receive benefits under the program. In different areas of law, lines of demarcation between those who are clearly employees and those who are entrepreneurs have been drawn at varying points. The courts in the formulation of the master-servant relationship for purposes of the common-law doctrine of respondeat superior, and in the interpretation of workmen's compensation statutes, have long wrestled with the problem of the nature and bounds of the employment relationship. It was necessary for draftsmen of the definition of "employment" in unemployment compensation statutes to project any choice of alternatives of language against the backdrop provided in those fields in order to anticipate in so far as possible, and thereby obviate, any carryover of distinctions which would have no place in unemployment compensation. This article is concerned with the nature of the definitions of the employment relationship which were incorporated in unemployment compensation laws, and the degree of success of the effort to formulate a specialized definition for unemployment compensation purposes.

This discussion is arranged in five parts: first, the nature of the common-law master-servant relationship, its historical background and its relevance for unemployment compensation purposes; second, special definitions of the employment relation contained in unemployment compensation laws; third, the manner in which such definitions have been interpreted by the courts; fourth, the judicial interpretation of unemployment compensation laws not containing such special definitions; and, finally, the implications of the decision of the Supreme Court in National Labor Relations Board v. Hearst Publications, Inc., ${ }^{1}$ upon the future interpretations of employment relation definitions in unemployment compensation statutes.

\section{The Common-Law Master-Servant Relationship}

At the beginning of the last century it was considered just to impose liability upon an entrepreneur for all harms tortiously committed in the course of services performed for him even though the actor was what later came to be called an "independent contractor," or the servant of

† Senior Attorney, Federal Security Agency.

1. 322 U. S. 111 (1944), reh'g denied, 322 U. S. 769 (1944). 
an independent contractor. ${ }^{2}$ Not until 1826 did a court carve out of that general liability an immunity of the principal where he procured services by engaging an independent contractor. ${ }^{3}$ In the development of this exception to the prior general rule of liability, whether the relationship of "independent contractor" existed depended principally, if not solely, on whether in the performance of the services the alleged independent contractor was in the pursuit of an independent calling. ${ }^{4}$ So considered, one who, with respect to the services in question, is not engaged in an independent calling would remain a "servant" of the principal. Whether or not the principal possessed a right of control over the actor in the performance of the services came to be discussed in the cases, but more as an explanation for not holding the principal liable where an independent contractor relationship existed than as a test of the existence of that relationship. But in time the test of control became the most prominent, if not the controlling criterion, and the concept of independent contractor was modified to include persons who were not subject to control even though they were not engaged in an independent calling.

The Restatement of the Law of Agency, in discussing rules for recovery against a principal for injuries caused by the tortious conduct of his servants, defines the master-servant relationship as follows:

"(1) A servant is a person employed to perform service for another in his affairs and who, with respect to his physical conduct in the performance of the service, is subject to the other's control or right to control.

"(2) In determining whether one acting for another is a servant or an independent contractor, the following matters of fact, among others, are considered:

(a) the extent of control which, by the agreement, the master may exercise over the details of the work:

(b) whether or not the one employed is engaged in a distinct occupation or business;

(c) the kind of occupation, with reference to whether, in the locality, the work is usually done under the direction of the employer or by a specialist without supervision;

2. In Bush v. Steinman, 1 Bos. \& P. 404, 126 Eng. Rep. R. 97 (C. P. 1799), the general employer was held liable for harm caused by a servant of a subcontractor of a contrastor who had been engaged to repair the general employer's house. See discuscions of this cass in Harper, The Basis of the Immannity of an Employer of an Independent Cortyeetor (1035) 10 IND. L. J. 491, 497; Stevens, The Test of the Ennployment Relation (1939) 33 Micr. L. REv. 188, 195; Wolfe, Determinzation of Employer-Employce Relationships in Social Legis!ation (1941) 41 CoL. L. REv. 1015, 1021.

3. Laugher v. Pointer, 5 B. \& C. 547, 108 Eng. Rep. R. 20\%, 207 (K. B. 1826), discussed in Harper, supra note 2, at 197; Stevens, supra note 2, at 192.

4. Thus, in Laugher v. Pointer, 5 B. \& C. 547, 555, 108 Eng. Rep. R. 204,207 (K. B. 1826), Littledale, J., said that a "jobman was a person carrying on a distinct employment of his own, in which he furnished men and let out horses . . . to all such percons as chose to employ him . . .", and, therefore, was an independent contractor. 
(d) the skill required in the particular occupation;

(e) whether the employer or the workman supplies the instrumentalities, tools, and the place of work for the person doing the work;

(f) the length of time for which the person is employed;

(g) the method of payment, whether by the time or by the job;

(h) whether or not the work is a part of the regular business of the employer; and

(i) whether or not the parties believe they are creating the relationship of master and servant." $b$

It will be noted that the so-called "control test" prescribed in paragraph (1) of Section 220 is stated as the governing criterion and that the factors listed in paragraph (2) appear to serve merely as factual bases from which inferences are to be drawn as to whether the control test is satisfied. 6 Some of the cases, however, do not conceive of the control test as the sole ultimate criterion, but rather seem to consider the second subsidiary factor, whether the one employed is engaged in a distinct occupation or business in the course of which he performs services for the principal, as a factor of independent and predominant significance. ${ }^{7}$ There is also a difference of view as to the content of the control test itself. Some courts insist upon a right to control all details of the physical performance, while others are satisfied with a showing that the principal has a "general control" over the person engaged."

5. Restatement, Agency (1933) $§ 220$. The Restatement adopts the substance, and in some respects almost the exact wording, of the factors described in the leading case, Murray's Case, $130 \mathrm{Me}$. 181, 154 Atl. 352 (1931); cf. factors (b), (e), (f), (g), and (h) of $\S 220(2)$ of the Restatement with factors (2), (4), (6), (7), and (8) in Murray's Case. See also Kinsman v. Hartford Courant Co., 94 Conn. 156, 108 Atl. 562 (1919); Neece v. Lee, 129 Neb. 561, 262 N. W. 1 (1935); American Nat. Ins. Co. v. Denke, 128 Tex. 229, 95 S. W. (2d) 370 (1936); Stockwell v. Morris, 46 Wyo. 1, 22 P. (2d) 189 (1933).

6. But see note 14 infra.

7. In Mullich v. Brocker, 119 Mo. App. 332, 338-9, 97 S. W. 549, 551 (1905) the court concluded: "It looks like the employee must have a calling in which it is fair to presume he has developed skill, before he will be regarded otherwise than as a servant. . . . he must hold himself out as having an occupation with which he is familiar." Regarding the control factor the court rejected the proposition that ". . . a person not especially qualified for a particular service, but ready to undertake any job which may be offered to him . . . becomes, when hired for some job, an independent contractor, simply because the employer relinquishes control over the work and trusts it to the employee's discretion." See Maltz v. Jackoway-Katz Cap Co., 336 Mo. 1000, 1013, 82 S. W. (2d) 909, 917 (1935); Southern Cotton Oil Co. v. Wallace, 23 Tex. Civ. App. 12, 16, 54 S. W. 638, 641 (1899).

8. In Aisenberg v. C. F. Adams Co., 95 Conn. 419, 111 Atl. 591 (1920) (workmen's compensation case applying common-law criteria), a commission salesman was free from control as to hours, method of transportation employed, prospects called upon, and territory covered. The court, applying common-law tests, held him to be an employee, stating: "The subject of sale, the terms of sale, and the proceeds of sale, remained in the control of the Company. Practically this constituted a general control." Id. at 422, 111 Atl. at 592. Fol. lowed in Lassen v. Stamford Transit Co., 102 Conn. 76, 128 Atl. 117 (1925) (negligence 
And some courts have held that the retention by the employer of a right of control over the physical performance of services is not a prerequisite at all, at least where it would seem an inconvenient or ineffi-

case); Bueil v. Danaher, 127 Conn. 606, 1S A. (2d) 697 (1941) (unemployment compansation coverage). See Burgess v. Garvin, 219 M1o. App. 162, 272 S. W. $10 S$ (1925) (negligence case, commission salesman); Singer MIfg. Co. v. Rahn, 132 U. S. 518 (18S9) (negligence case, commission salesman); U. S. Fidelity \& Guaranty Co. v. Lowry, 231 S. IY. 818 (Tex. Civ: App. 1921) (workmen's compensation, commission salesman); Chatelain v. Thaelieray, 98 Utah 525, 100 P. (2d) 191 (1940) (automobile negligence case, commission insurance salesman); Dillon v. Prudential Ins. Co., 75 Cal. App. 266, 242 Pac. 736 (1925).

The power of the principal to discharge the employee at will or upon short notice has been given greater prominence by many courts than is indicated by the Restatement. L. B. Price Mercantile Co. v. Industrial Comm., 43 Ariz. 257, 30 P. (2d) 491 (1934); Press Publishing Co. v. Industrial Accident Comm., 190 Cal. 114, 210 Pac. $\$ 20$ (1922); N. Y. Indemnity Co. v. Industrial Accident Comm., S0 Cal. App. 713, 252 Pac. 775 (1927); Industrial Comm. v. Hammond, 77 Colo. 414,236 Pac. 1006 (1925); Industrial Comm. v. Bonfils, 78 Colo. 306, 241 Pac. 735 (1925); Aisenberg v. C. F. Adams Co., 95 Conn. 419, 111 Atl. 591 (1920); Franl-lin Coal and Coke Co. v. Industrial Comm., 296 Ill. 329, 129 N. E. 811 (1921); Clark's Case, 124 Me. 47, 126 Atl. 18 (1924); Matter of Glielmi v. Netherland Dairy Co., 254 N. Y. 60, 171 N. E. 906 (1930); Journal Pub. Co. v. Unemployment Comp. Comm., 155 P. (2d) 570 (Ore. 1915); Cockran v. Rice, 26 S. D. 393, 128 N. W. 583 (1910). The fo!lowing statement, from 14 RULING CASE LAW 72, is often quoted in the cases: "The power of an employer to terminate the employment at any time is incompatible with the full control of the work which is usually enjoyed by an independent contractor, and hence is considered as a strong circumstance tending to show the subserviency of the employee. Indeed, it has been said that no single fact is more conclusive, perhaps, than the unrestricted right of the employer to end the particular service whenever he chooses, without regard to the final result of the work itself." Some courts have held it to be the most important of all factors. L. B. Price Mercantile Co. v. Industrial Comm., 43 Ariz. 257, 30 P. (2d) 491 (1934); Industrial Comm. v. Bonfils, 78 Colo. 306, 241 Pac. 735 (1925). In the Bonfls case the court concluded: "By virtue of its power to discharge, the company could at any" moment direct the minutest detail and method of the work." Id. at 308, 241 Pae. at 736. Perhaps in emphasizing the power of discharge the courts are really thinling of the economic dependence of the worker. In Speculations as to "Respondeat Superior" in Hanvaro LeG.aL Essays (1931) 433, 458, n. 9, Professor Seavey concludes, "It is quite true that in most of the master and servant situations there is no physical control by the master, but the relationship carries with it a power of control over the servant through his economic subjection. ..."

A closely related factor which has also been accorded very great weight by many courts is whether the person employed is engaged for the performance of a specific piece of rork and has a contract right to complete the work. In Coclran v. Rice, 26 S. D. 393, 123 N. W. 583 (1910), the court concluded that the contract is one of employment unless it is for a certain definite and specified result, and contemplates a definite beginning, continuance, and ending. In Industrial Comm. v. Bonfils, 78 Colo. 306, 309, 241 Pac. 735, 736 (1925), the court illustrated the relationship of this factor to the povier of discharge and to the control test: "If I hire Smith to plow for me at $\$ 4.00$ per acre he is my servant; if Smith agrees to plow: my 20 acres at four dollars per acre and I agree to pay him that sum for it he is an independent contractor. In the first case I can discharge him at will and therefore control him. In the second I cannot discharge him or control him except as to result." See Aisenberg v. C. F. Adams Co., 95 Conn. 419, 111 Atl. 591 (1920); Burruss v. B. M. C. Logging Co., 38 N. M. 254, 31 P. (2d) 263 (1934); Beach v. Velzy, 23S N. Y. 100, 143 N. E. 805 (1924). 
cient arrangement, or where the skill of the employee makes it unnecessary. ${ }^{9}$

The soundness of insulating a general employer from liability on the basis of the control test has been severely criticized. Some critics have desired a much greater emphasis on the independent-calling test, making it either controlling or at least independently significant. ${ }^{10}$

9. For a situation in which the inconvenience of control by employer made it unnecessary, see Mullich v. Brocker, 119 Mo. App. 332, 97 S. W. 549 (1905). In Allied Mutuals Liability Ins. Co. v. De Jong, 209 App. Div. 505, 205 N. Y. Supp. 165 (1st Dep't 1924) (workmen's compensation) an industrial homeworker was held an employee, the court stating: "One may be sent into a forest to fell trees or be sent to his home to sew garments, and in either case be none the less an employee. If the employer chooses to order work so done as to waive supervision, this does not make the employee less an employee." Id at 507, 205 N. Y. Supp. at 167. Accord: Fischer v. Industrial Comm., 301 Ill. 621, 134 N. E. 114 (1922); Andrews v. Commodore Knitting Mills, Inc., 257 App. Div. 515, 13 N. Y. S. (2d) 577 (3d Dep't 1939). In Kaus v. Huston, 35 F. Supp. 327, 331 (N. D. Iowa 1940) the court concluded, ". . . there is no discretion vested in the [taxi] drivers inconsistent with the relation of master and servant. From the very nature of the case the drivers, in order to perform their duties properly, must exercise very complete control over the cabs while they have them out on their shifts."

For cases in which skill of employee made retention of control unnecessary, see United States v. Butler, 49 F. (2d) 52 (C. C. A. 5th, 1931) (lawyer); Matter of Bernstein, 236 N. Y. 268, 140 N. E. 694 (1923) (physician).

10. The decisiveness of the independent calling test appears principally in commission salesmen cases; it is largely in such cases that courts seem to have the most difficulty in clearly explaining and consistently applying the control test. It has been suggested that the control test, although it may have been appropriate in the early part of the industrial era, no longer meets the realities of modern business organization.

“. . . expansion of industrial organizations in size and function have been accompanied by a considerable decentralization of authority and delegation of duties. This process is graphically illustrated by the status of salesmen. The gradual elimination of the jobber or wholesaler has been paralleled by an enormous increase in the sales organizations of manufacturing establishments which themselves now undertake the function of distribution either to the retailer or directly to the consumer. Companies manufacturing various types of home appliances, apparel, or food products frequently build up large forces of dealers, distributors, and agents who are subject to only such controls as seem practicable considering the nature of the job and the geographical scope of their operations. . . . They may have considerable latitude of discretion as to means of transportation, hours of work, and methods of selling, but stardards will frequently be 'suggested' by the company concerned, a deviation from which, accompanied by a failure to make the volume of sales expected, can result in immediate dismissal. . . .

". . . In many cases it seems clear that the nature of the services are such, or they are performed at such a distance from the alleged employer, that any attempted exercise of the right [of control] would be impracticable although they aro performed in the course of furthering the business of another and not in an independently established business of the person who performed them."

Issues Involved in Determining Eligibility Under the Old-Age and Sturvirors Insurance Program in Soctal Security Yearbook: 1941 (1942) 47, 49, 51. Leidy, Salesmen as Independent Contractors (1930) 28 Micr. L. Rev. 365, 375, proposes that the independent calling test be given primary weight. See also Wolfe, supra note 2 , at 1024. 
The question seems to be largely one of premises. The emphasis on control seems more in harmony with the notion of fault, "the supposed basis of liability for torts of negligence," 11 or the purpose of holding liable those in a position to minimize risk. ${ }^{12}$ The emphasis upon independent calling, on the other hand, would perhaps be more in harmony with the purpose of securing persons against the risk of serious loss from tortious harms by distributing the loss more videly. ${ }^{13}$

The specifications of factors by the Restatement and in the numerous court decisions do not provide any precise formula for their application. ${ }^{14}$ As is the case in many other areas of law, it is easier to state the rule than to apply it. The result in a particular case is governed by a weighing of all the factors in the light of the facts, and is almost completely "a matter of judgment." It is not surprising, therefore, to find differences in result where the fact situations differ very little, because courts conceive differently the factors to be applied and give them greatly varying weights. ${ }^{15}$

11. Steffen, Independent Contractor and the Good Life (1935) 2 U. of Car. L. Rcv. 501, 506. This does not explain adequately the large area in which the employer, even when circumspect in the choice of servants, has been held liable for the latter's unauthorized wrongs. See Neuner, Respondeat Supcrior ist the Light of Comparative Lrso (19:1) \& LA. L. REV. 1, 7, in which the author concludes, ". . . a legal rule which malses the mastcr's lisbility depend upon his own negligence introduces an element of unreality and uncertainty into the law beyond all tolerable limits. It is unrealistic to require a degrice of care in salestion and control which as a practical matter cannot be exercised."

12. Douglas, Vicarious Linbility ard Administration of Risls (1929) 33 YALE L. J 5SA, 587-8, 598, 601 ("risk prevention"). It is questionable whether the dostrine fsrves as a preventive influence rather than as an ex post facto determination of who chall bear the locs. See Harper, supra note 2, at 498 .

13. Harper, supra note 2, at 500, suggests that the immunity of an employer of an independent contractor may be progressively limited and eventually eliminated in favor of persons injured in the conduct of the employer's affairs. Neuner, stter note 11, at 21-2 proposes, as the most rational test, that the entrepreneur be liable for injuries causal by all persons engaged by him except other entrepreneurs, while the consumer (c.g., a housawife engaging a plumber for repair work) should be liable only for harmful acts of servants in the popular sense of the word. See Sinclair v. Perma-MIaid Co., $345 \mathrm{~Pa} .280,26 \mathrm{~A}$. (2d) 924 (1912) in which defendant corporation was held liable for injuries causad by the negligent operation of an automobile ormed and driven by its salesman who was engaged on a commission basis to demonstrate its line of utensils. The court held that because the use of the automobile was of "vital importance" to the company in furthering the company's tusine:s, it could be inferred that actual or potential control was reserved. Note (1912) 8 U. of Pitss. L. Rev. 270.

14. The Restatement observes: "The relationship of master and servant is one not capable of exact definition . . . . It cannot ... be defined in general terms with substantial accuracy. The factors stated in Subsection (2) are all considered in determining the question, and it is for the triers of fact to determine whether or not there is a sufficient group of favorable factors to establish the relationship." REsTatrusent, AGE:icy (1933) 8220 , Comment (1)b.

15. In Burchett v. Department of Labor, 146 Wash. 85, 88-9, 261 Pac. 802 , 803-4 (1927), the court stated, "The distinction between an employee or eervant and an inde- 
Nor do definitions governing coverage under workmen's compensation statutes offer much guidance. They generally are not elaborate but consist simply of words ("employee," "employer," "contract of hire," "employment") which are well known in the common-law cases. As a consequence the courts, in the interpretation and application of the definitions, resort to the master-servant relationship commonly applied in the law of respondeat superior. ${ }^{16}$ Some courts, deferring to the remedial purpose of such legislation, have inclined in doubtful cases to resolve the doubt in favor of the worker, ${ }^{17}$ and a few judges have urged that statutes not departing substantially from others in definition have a broader coverage than the master-servant relationship. ${ }^{18}$

\section{Definition of "EMPLOYMENT" in UnEMPLOyment Compensation StatuTES}

The tests for determining who is an employee for purposes of the doctrine of respondeat superior should of course be consistent with the purposes which that doctrine is conceived to achieve, and should be modified as social policy dictates that the purposes be modified. Thus, the control test may logically be employed as the touchstone of respondeat superior if the distribution of risk is to be administered on the theory of holding principals who are at fault or in a position to minimize risk, and if such a test is conceived to serve such a purpose. But such a test has no necessary relation to the purposes of a program whose object is to insure against the risk of unemployment and compensate unemployed persons for their wage loss. ${ }^{19}$ For example, even assuming

pendent contractor has been considered by the courts in numberless cases, but no statement of the rule has yet been made which perfectly fits every case . . . . While we have read the great many cases cited by the parties in their briefs, and others to which they referred, the confusion is so great and distinctions so intricate that we see no benefit in citing or discussing them."

16. Birmingham Post Co. v. Sturgeon, 227 Ala. 162, 149 So. 74 (1933); County of Los Angeles v. Industrial Accident Comm., 123 Cal. App. 12, 11 P. (2d) 434 (1932); Press Pub. Co. v. Industrial Accident Comm., 190 Cal. 114, 210 Pac. 820 (1922); VanWatermeullen v. Industrial Comm., 343 Ill. 73, 174 N. E. 846 (1931); Hayes v. Board of Trustees, 224 N. C. 11, 29 S. E. (2d) 137 (1944); Hinds v. Department of Labor and Industries, 150 Wash. 230, 272 Pac. 734 (1928); Note (1926) 43 A. L. R. 335, 346.

17. See notably Hight v. Industrial Comm., 44 Ariz. 129, 34 P. (2d) 404 (1934); Marshall Field \& Co. v. Industrial Comm., 285 Ill. 333, 120 N. E. 773 (1918); Fischer v. Industrial Comm., 301 Ill. 621, 134 N. E. 114 (1922); Meek v. Julian, 219 Ind. 83, 36 N. E. (2d) 854 (1941); Allied Mutuals Liability Ins. Co. v. De Jong, 209 App. Div. 505, 205 N. Y. Supp. 165 (1st Dep't 1924).

18. See discussion in Matter of Rheinwald, 168 App. Div. 425, 153 N. Y. S. 598 (3d Dep't 1915), award rev'd, 174 App. Div. 935, 160 N. Y. Supp. 1143 (3d Dep't 1916), aff'd, 223 N. Y. 572, 119 N. E. 1074 (1918); and Judge Wolfe's dissent in Stover Bedeling Co. v. Industrial Comm., 99 Utah 423, 428, 107 P. (2d) 1027, 1029 (1940).

19. See Comment (1942) 36 Ill. L. Rev. 873. 
that an employer is in a position to minimize the risk of unemployment, ${ }^{20}$ his power to do so is in no manner related to whether he retains a quantity or quality of control which meets respondeat superior tests. The fact that an employee is left largely to his own devices in performing services in the furtherance of his principal's business does not lessen his dependence for his economic survival upon the continuance of the employment and the remuneration flowing therefrom. If the risk of causing tortious harm to others may be minimized substantially by controlling the employee's performance of services, the risk of insecurity of the employee cannot. And if the placing of considerable discretion in the employee in the performance of his duties lessens the employer's responsibility for tortious injuries, it cannot lessen the employee's reliance upon his job relationship with the employer as the basis of his livelihood.

Apparently such were the convictions of the draftsmen of most of the unemployment compensation laws, for they expressed a desire to extend the protection of those laws to persons who might not be deemed employees under the legal concepts governing the liability of a master for tortious acts of his servant. ${ }^{21}$ The statutory definition of employment recommended by them, and incorporated in the draft unemployment compensation law prepared by the Social Security Board, 22 was patterned after the existing Wisconsin statute ${ }^{23}$ and is commonly called the " $A B C$ " definition. It was adopted by most of the states in the following form:

"(1) Employment ... means service ... performed for wages or under any contract of hire, written or oral, express or implied....

20. The validity of this assumption is discussed elsewhere in this issue of the Journol. See Arnold, Experience Rating, page 218 infra, at 220. Cf. Schmidt, Exparience Rating and Unemployment Comperzsation, 218.

21. At the time when most unemployment compensation laws were in the drafting stage (October 1936), the Committee on Legal Affairs of the Interstate Conference of Cnemployment Compensation Agencies unanimously agreed that the test of coverage "should not be confined to the technical legal relationship of master and servant." The Committce gave as reasons the general purposes of such laws and the belief that restriction of coverage to "the technical legal relationship of master and servant constitutes an obvious avenus of evading coverage by creating different legal relationships, for example, an independent contractor relationship." The Committee recommended that a definition of employment similar to that contained in the Wisconsin unemployment compensation law be incorporated in State laws "as the basis for extending their coverage beyond the master and servant relationship." Report of Committee, p. 2.

22. The draft bill first containing the "ABC" definition recommended by the Interstate Conference was issued in January 1937.

23. The "ABC" definition was incorporated in the Wisconsin act by Vis. Laws 1935, c. $192, \S 5$. The Wisconsin Advisory Committee, a statutory body created to advice the legislature in matters of unemployment legislation (among other functions) deccrited the statutory definition which it recommended to the 1935 legislature as providing a definition which "is unique and exists only in the field of unemployment compeneation and . . . is to be considered apart from conceptions of employer-employee relationships exieting in other fields." Explanation of Changes, Bill No. 426, S., 1941 Legislature. 
"(5) Services performed by an individual for wages shall be deemed to be employment subject to this act unless and until it is shown to the satisfaction of commissioner that-

(a) such individual has been and will continue to be free from control or direction over the performance of such service, both under his contract of service and in fact; and

(b) such service is either outside the usual course of the business for which such service is performed or that such service is performed outside of all the places of business of the enterprise for which such service is performed; and

(c) such individual is customarily engaged in an independently established trade, occupation, profession or business."

The laws of a few states contain the "ABC" definition with variations which either tend to broaden coverage ${ }^{24}$ or restrict it in minor degree. ${ }^{25}$ In a number of states, the "ABC" definition has been so modified as to restrict considerably its applicability, ${ }^{26}$ in some by the specific provision that common-law principles of the master-servant relationship shall govern. ${ }^{27}$ The laws of seven states ${ }^{28}$ do not contain any of the three tests, but define employment as "service . . . performed for wages, or under any contract of hire, written or oral, express or implied," ${ }^{29}$ or use terms such as "service .. . performed by an employee," 30 "the relationship of employer and employee," 31 or "contract of employment," 32 without further definition of those terms.

24. Oklahoma uses the conjunctive in the second test; Arizona, Florida, Hawaii, Mary. land, Nevada, New Mexico, Oregon (which deletes the second test), Utah, and Washington add to the third test the words "of the same nature as that involved in the contract of serv. ice"; Maryland, North Dakota and Hawaii have inserted in the clause introducing the three tests the words "irrespective of whether the common law relationship of master and servant exists."

25. Kansas omits the third test; Virginia makes the second and third tests disjunctive; Wisconsin's definition has been modified and now provides substantially the first and third tests.

26. Idaho, Iowa, Massachusetts, and Texas include only the first test; South Dakota makes the three tests disjunctive; Indiana omits the second test and adds to the third the words "or is an agent receiving remuneration solely upon a commission basis, and who is the master of his own time and effort"; regarding Ohio, see note 91 infra.

27. Alabama, Arkansas (the statute also includes the three tests in the disjunctive), Minnesota (which oddly makes this test an alternative to the three-test definition), and Mississippi.

28. California, Colorado, Connecticut, District of Columbia, Kentucky, Michigan, and New York.

29. California, District of Columbia, and Michigan (which substitutes "remuncration" for "wages"). The Michigan law formerly contained the "ABC" test. See note 46 infra.

30. Colorado. This law at one time contained the "ABC" test. See note 37 infra.

31. Connecticut (prior to Oct: 1, 1943 the words "master and servant" were in place of "employer and employee"), and Kentucky.

32. New York. 
In all states, apart from the specificity of the "ABC" definition where it is used, and despite its absence where it is not used, the draftsmen could hope that the courts would look to the purposes of the legislation and construe its provisions consistently with its policy objectives. ${ }^{33}$ Most of the state acts contain a declaration of policy like the following:

"As a guide to the interpretation and application of this Act, the public policy of this state is declared to be as follows: Economic insecurity due to unemployment is a serious menace to the health, morals, and welfare of the people of this state resulting in a public calamity. The Legislature, therefore, declares that in its consid- ered judgment the public good and the general welfare of the citizens of this state require the enactment of this measure, under the police powers of the state, for compulsory setting aside of unemployment reserves to be used for the benefit of persons unemplayed through no fault of their own." 34

The declaration emphasizes what would be evident even without it: that the statute is remedial legislation with a broad purpose to avoid economic insecurity. Thus, at whatever line the limits of the employment relationship might be drawn for various other purposes, with respect to unemployment insurance the definitions of "employment" should be interpreted with a view toward effectuating the underlying policy of the legislation. Workers falling on either side of the line of demarcation drawn for respondeat superior purposes may be within the class exposed to the hazard against which the unemployment insurance legislation is intended to afford protection. ${ }^{35}$

33. See Landis, Statules and the Sources of Lato (1934) Harvard Leg.lL Essays 213. The Restatement offers this word of caution: 'Statulory use of 'serianl.' Statutes have been passed in which the words 'servant' and 'agent' have been used. The meaning of theze words in statutes varies. The context and purpose of the particular statute controls the meaning which is frequently not that which the same vord bears in the Restatement of this Subject." Restatesient, Agency (1933) § 220, comment (1)d.

34. Missouri Unemployment Compensation Act $\S 2,20$ Mo. Rev. St.It. Awr. (19:3) $\S 9122$.

35. In Lehigh Valley Coal Co. v. Yensavage, 218 Fed. 547, 552 (C. C. A. 2d, 1914), cert. denied, 235 U. S. 705 (1915), involving workmen's compeneation coverage, Judge Hand said: "It is true that the statute uses the word 'employed,' but it must be understood with reference to the purpose of the act, and where all the conditions of the relation require protection, protection ought to be given . . . . Such statutes are partial; they upzet the freedom of contract, and for ulterior purposes put the two contesting sides at unequal advantage; they should be construed, not as theorems of Euclid, but with some imagination of the purposes which lie behind them." To similar effect see International Stevedoring $C_{0}$. Haverty, 272 U. S. 50 (1926); Warner v. Goltra, 293 U. S. 155 (1934); Fox v. Standard Oil Co., 294 U. S. 87 (1935); United States v. American Trucling Ass'ns Inc., 310 U. S. 534 (1940); NLRB v. Hearst Publications, Inc., 322 U. S. 111 (1944). 


\section{Judrcial Interpretation of Statutes Using "ABC" Definition Content of the " $A B C$ " Definition.}

The reader will note first that the "ABC" definition does not contain any of the words with common-law connotations-"master," "servant," "employee," or "independent contractor." The draftsmen might have used such and relied hopefully upon the general recognition that terms may have a meaning varying from their common-law meaning when used in remedial legislation. But in the unemployment compensation laws adopting the three-test definition, not only were those terms not contained in the definition, but there was an obviously studied effort to avoid such connotations by not using such terms anywhere in the acts. The wage earner is referred to ordinarily as an "individual." An employer's liability for payment of contributions into the unemployment compensation fund is based upon the payment by him of "wages" for "employment." Entitlement of a claimant for benefits is based upon the amount of "wages" he has been paid for "employment." "Wages" is defined broadly as remuneration for services. Thus, both the question of contribution liability and of benefit entitlement depend upon whether the services are performed in "employment," which is the subject of a single statutory definition.

Unlike the Restatement, which stresses the process under the common law of weighing the nine listed factors to determine whether or not there is a sufficient group of favorable factors to establish the master-servant relationship, the statutory definition includes in "em. ployment" all services performed for wages unless and until it is shown to the satisfaction of the administrative agency that each of three positive tests is met. Each test is separate, has a distinct significance, and exists on a coördinate basis with each of the other two. Thus, positive legislative standards are substituted for factors of varying and uncertain weight. ${ }^{36}$

The " $A$ " Test. The first test, that the "individual has been and will continue to be free from control or direction over the performance of his services both under his contract of service and in fact" appears different in certain respects from Restatement factor (1), "the extent of the control which by the agreement the master may exercise over the details of the work." To meet this statutory test it must appear that the contract does not confer upon the principal any right of con-

36. Certain of the factors described in the Restatement are not touched on by the statutory definition: the kind of occupation and the customs of the locality with respect to it; the skill required in the particular occupation; who furnishes the tools; the length of time for which the person is employed; the method of payment, by time or by the job; whether the parties believe they are creating the master-servant relationship. Although some of the substance of the remaining factors of the Restatement is reflected in some measure in the statutory criteria, they serve merely as part of the raw material out of which the statutory definition was constructed. 
trol or direction over the performance of such services, and that he has not exercised and will not exercise such control or direction in fact. The possibility of control in the future would thus seem to be as decisive as present control. It is not wholly clear what freedom from control "over the performance of services" means, but the omission of any reference to physical performance or to manner and means of work indicates that freedom from common-law control alone vould not satisfy the test. It would seem that the existence or possibility of a "general control" as known in some of the common-law cases would still leave the test unsatisfied.

The " $B$ " Test. The second test which must be met to establish the absence of the employment relationship requires that the service in question be "outside the usual course of the business for which such service is performed," or "performed outside of all the places of business of the enterprise for which such service is performed." The first alternative is satisfied only if the activity is not part of the business of the principal. This alternative would not be satisfied by the fact that the person engaged to perform the services does so pursuant to his ovn independently established business; the service must be out of the usual course of the principal's business. While the first alternative is concerned with whose business is being carried on, the second alternative seems to be concerned with where it is being carried on.

The " $C$ " Test. The third test, requiring a showing that "such individual is customarily engaged in an independently established trade, occupation, profession or business," appears to be at once the most radical departure from common-law criteria and the most relevant of the three tests to the purposes of the unemployment compensation program. In determining the point between the clearly servant status and the self-employed class at which the line of coverage for unemployment insurance is to be drawn, it seems most appropriate to distinguish between the person who pursues an established business of his own, who is not ordinarily dependent upon a particular business relationship with another for his economic survival, and other persons who are dependent upon the continuance of their relationship with a principal for their economic livelihood. Under the statutory definition the words "independently established" depart from the technical "independence" of the common-law independent contractor and seem to require that the individual performing services be engaged in a trade, occupation, profession, or business which is established independently of the particular connection he may have from time to time with certain principals. The words "customarily engaged" would seem to require that he customarily hold himself in readiness to render services in the course of such trade, occupation, profession, or business to individuals desiring to engage him, and would appear not to be satisfied where the trade, occupation, profession, or business exists only in a 
particular relationship with a principal and would vanish when that connection terminates.

The " $C$ " test, in summary, seems to draw the line of demarcation on an economic basis, so as to include within the Act those who perform services for an entrepreneur and who are not themselves acting as entrepreneurs in that connection in the pursuit of an independently established business, trade, or profession. Moreover, being essentially a test of economic status and existing independently of the " $A$ " test relating to control, the " $\mathrm{C}$ " test precludes the "manipulation" of the employment relationship which the control test makes possible for employers, who may so draw the contract of employment and so arrange their methods of supervision that an appearance of freedom from control is created.

\section{Majority View: " $A B C$ " Definition Given Full Application.}

One of the first cases testing the scope of the "ABC" definition was Industrial Commission v. Northwestern Mutual Life Insurance Company, ${ }^{37}$ involving the coverage of commission life insurance salesmen. In its analysis of the definition, the Colorado Supreme Court concluded:

"When defining or referring to 'wages,' 'employment,' 'employer' and 'benefits' in the act the legislature deliberately avoids the use of the word 'employee,' and uses the much broader term, 'individual.' That this indicates legislative intent as to who is covered, cannot be doubted. The terms 'independent contractor' or 'master and servant' nowhere appear. The act prescribes the statutory test . . . and we must not be led astray by any other criterion. ...

". . . Here the statutory definition of 'employment' is broad and inclusive, and it cannot be so construed as to limit the meaning to the relationship of master and servant without violating the legislative intent. ${ }^{38}$

"This statutory definition sets forth three conditions, and they are in the conjunctive. A showing of conformity with all three, to the satisfaction of the commission, is a prerequisite to exemption from coverage under the law." 39

That case was soon followed by the decision of the North Carolina Supreme Court in a case which also involved coverage of commission

37. 103 Colo. 550,88 P. (2d) $560 .(1939)$.

38. Id. at 555-6, 88 P. (2d) at 563 .

39. Id. at 554, $88 \mathrm{P}$. (2d) at 562. Followed in Equitable Life Ins. Co. v. Industrial Comm., 105 Colo. 144, 95 P. (2d) 4 (1939); Brannaman v. International Service Union Ass'n, 108 Colo. 409, 118 P. (2d) 457 (1941). The statute was subsequently amended to eliminate the " $A B C$ " definition. 
life insurance salesmen. Commenting that the terms in the act "are not used as words of art having rigid, precise and restricted meanings, but rather . . . as broad terms of description, evidencing a legislative intent to give to the Act a broad and liberal coverage to the end that the far-reaching effects of unemployment may be alleviated," the court observed:

"The scope and purpose of the present act are exceptional in breadth. The draftsmanship of the definition section, which gives flesh and sinew to the whole, shows a carefully considered and deliberate purpose to leap many legal barriers which would halt less ambitious enactments. As far as language will permit it, the act evinces a studied effort to sweep beyond and to include, by redefinition, many individuals who would have been otherwise excluded from the benefits of the act by the former concepts of master and servant and principal and agent as recognized at common law." 49

Similar conclusions were reached by the courts of the following states in which the " $A B C$ " provisions substantially as quoted above were

40. Unemployment Comp. Comm. v. Jefferson Standard Life Ins. Co., 215 N. C. 479. 486, 2 S. E. (2d) 584,589 (1939). See also North Carolina v. Nat. Life Ins. Co., 219 N. C. 576,14 S. E. (2d) 689 (1940).

The Utah Supreme Court analyzed in more detail the setting of the definition in the scheme of the statute:

". . . it seems clear to us that the legislature has endeavored to define by the Act itself a classification of individuals entitled to employment benefits. Hence, the statutory definition, rather than any common law concepts, if differing therefrom, govern-in so far as they are applicable. The fact that neither the term 'cmployee' nor the term 'independent contractor' is used anywhere in the Unemployment Compensation Act is itself indicative that the legislature did not intend to use the relationships of 'independent contractor' or 'employer-employee,' as defined by the common law, as the criteria to determine who are entitled to benefits under the Unemployment Compensation Act. The word 'individual' is used throughout the Act to refer to the person seeking unemployment benefits. While the terms ' $\mathrm{cm}$ ployer' and 'employing unit' are used, they are specifically defined by the Act so that they have a distinct meaning which may or may not coincide with the ordinary conception of 'employer.' "

Creameries of America v. Industrial Comm., 98 Utah 571, 576, 102 P. (2d) 300, 302 (1910); Globe Grain \& Milling Co. v. Industrial Comm., 98 Utah 36, 91 P. (2d) 512 (1939). decisiors amended on motion for reli'g, 98 Utah 48, 97 P. (2d) 582 (1939). See also Salt Lalse Tribune Pub. Co. v. Industrial Comm., 99 Utah 259, 102 P. (2d) 307 (1910); National Tunnel \& Mines Co. v. Industrial Comm., 99 Utah 39, 102 P. (2d) 508 (1940); Combined Metals Rcduction Co. v. Industrial Comm., 101 Utah 230, 116 P. (2d) 929 (1941); Singer Sosing Machine Co. v. Industrial Comm., 104 Utah 175, 134 P. (2d) 479 (1943), affd on rel'g, 104 Utah 196, 141 P. (2d) 694 (1943); Northern Oil Co. v. Industrial Comm., 104 Utah 353, 140 P. (2d) 329 (1943); Utah Hotel Co. v. Utah Industrial Comm., 151 P. (2d) 467 (Utah Sup. Ct. 1914). 
adopted: Arizona, ${ }^{41}$ Arkansas, ${ }^{42}$ Georgia, ${ }^{43}$ Illinois, ${ }^{44}$ Indiana, ${ }^{46} \mathrm{Michi-}$

41. Sisk v. Arizona Ice \& Cold Storage Co., 60 Ariz. 496, 500, 141 P. (2d) 395, 396 (1943), the court stating: "The framers of this legislation evidently were familiar with the laws in the feld occupied by the laboring man and the problems pertaining thereto . . . . It quite clearly appears that the relationship need not be that of master and servant or employer and employee or principal and agent." See also Gaskin v. Wayland, 61 Ariz. 291, 148 P. (2d) 590 (1944).

42. McKinley v. Payne and Son Lumber Co., 200 Ark. 1114, 1118, 143 S. W. (2d) 38, 40 (1940): ". . . whether he [lumber stacker] would be classed as an independent contractor under the common law, we think, is immaterial because under the Unemployment Compensation Act he was an employee." However, after the Arkansas law was amended to apply "only where the legal relationship of master and servant exists," the court in a case involv. ing application of the prior law concluded that although the " $\mathrm{ABC}$ " tests were not met the alleged employees did not receive remuneration for personal services. McCain v. Crossett Lumber Co., 206 Ark. 51, 174 S. W. (2d) 114 (1943).

43. Young v. Bureau of Unemployment Comp., 63 Ga. App. 130, 10 S. E. (2d) 412 (1940). In Huiet v. Great Atlantic and Pacific Tea Co., 66 Ga. App. 602, 18 S. E. (2d) 693 (1942) the Court of Appeals held that before the "ABC" test is applied a service relationship must be found to exist, which depends upon whether control is exercised by the principal. See discussion of Fuller Brush Co. v. Industrial Comm., pages 95-8 infra. Subsequent decisions of the Georgia Supreme Court and Court of Appeals, however, have not adhered to that view. Zachos v. Huiet, $195 \mathrm{Ga}$. 780, 25 S. E. (2d) 806 (1943); Royal Cigar Co. v. Huiet, $195 \mathrm{Ga}$. 852, 25 S. E. (2d) 810 (1943); Johnson v. Huiet, 67 Ga. App. 638, 21 S. E. (2d) 437 (1942); Babb \& Nolan v. Huiet, 67 Ga. App. 861, 21 S. E. (2d) 663 (1942); Brewster v. Huiet, 69 Ga. App. 593, 26 S. E. (2d) 198 (1943); Union Dry Goods Co. v. Cook, 71 Ga. App. 708, 32 S. E. (2d) 190 (1944).

44. A. George Miller, Inc. v. Murphy, 379 Ill. 524, 42 N. E. (2d) 78 (1942); Rozran v. Durkin, 381 Ill. 97, 45 N. E. (2d) 180 (1942); Peasley v. Murphy, 381 Ill. 187, 44 N. E. (2d) 876 (1942) (in which the court held the statutory definition sufficiently comprehensive to include all workers to whose security unemployment is a threat). Two decisions in 1943, Ozark Minerals Co. v. Murphy, 384 Ill. 94, 51 N. E. (2d) 197 (1943), and Toplis and Harding, Inc. v. Murphy, 384 Ill. 463, 51 N. E. (2d) 505 (1943), temporarily confused the situation in the interpretation of other provisions of the law designed to determine who is the employer rather than whether a person is in employment. The situation was subsequently clarified in decisions in which the contrast between the broad statutory definition and the narrow common law criterion was again emphasized. Murphy v. Daumit, 387 III. 406, 56 N. E. (2d) 800 (1944); Zelney v. Murphy, 387 Ill. 492, 56 N. E. (2d) 754 (1944); N. Y. Life Ins. Co. v. Murphy, 388 Ill. 316, 58 N. E. (2d) 182 (1944) (which clearly restricted the scope of the Ozark Minerals and Toplis and Harding decisions); Arrow Petroleum Co. v. Murphy, 389 Ill. 43, 58 N. E. (2d) 532 (1944); John Gabel Mfg. Co. v. Murphy, 62 N. E. (2d) 401 (Ill. 1945); Photographic Illustrations, Inc. v. Murphy, 59 N. E. (2d) 681 (Ill. 1945); Van Ogden, Inc. v. Murphy, 60 N. E. (2d) 877 (11l. 1945). See In re Mid America Co., 31 F. Supp. 601 (S. D. Ill. 1939) in which the court interpreted the Illinois Unemployment Compensation Act to the same effect. $C f$. Beth Weber, Inc. v. Murphy, 58 N.E. (2d) 913 (I11. 1945).

45. Park Improvement Co. v. Review Bd., 109 Ind. App. 538, 36 N. E. (2d) 985 (1941); Review Bd. v. Mammoth Life and Accident Ins. Co. 111 Ind. App. 660, 42 N. E. (2d) 379 (1942). Cf. News Publishing Co. v. Verweire, 113 Ind. App. 451, 49 N. E. (2d) 161, 113 Ind. App. 451 (1943). 
gan, ${ }^{46}$ New Jersey, ${ }^{47}$ Oregon, ${ }^{48}$ Utah, ${ }^{49}$ Virginia, ${ }^{29}$ Washington, ${ }^{51}$ Wisconsin. ${ }^{52}$

The decisions in these states have not very clearly developed the content of the first test. By and large, the courts have not seemed to give the first test a very different meaning than they would have the common-law control test. The Colorado, Illinois, and Washington courts, however, have stated that this test is not concerned with "details" of control but with "general control"; $\$ 3$ but how much less

46. In Bert Baker, Inc. v. Ryce, 301 Mich. 84, 3 N. W. (2d) 20 (1942), the Supreme Court quoted only the " $\mathrm{A}$ " test of the definition and proceeded to hold a leszse car mechanic an independent contractor because the common law test was not satisficd, without mention or application of the remaining two tests. However, in Acme Messenger Service Co. v. Unemployment Comp. Comm., 306 Mich. 704, 11 N. W. (2d) 196 (1943), the court held the previous decision inapplicable, gave full scope to the statutory definition, and held parsons delivering packages and messages for a messenger company to be in employmont. Sutssquently in O'Brian v. Unemployment Comp. Comm., 309 Aitch. 18, 14 N. W. (2d) 560 (1944), involving coverage of appliers of roofing and siding, the court reiterated the viev; expressed in the Acme case, that the statute furnishes its own test of the employment relationship. In $19 \pm 3$ the statute was amended by the deletion of the "ABC" test. Mfich. Laws 1913, Act 246.

47. Schomp v. Fuller Brush Co., 124 N. J. L. 487, 12 A. (2d) 702 (1910); Steal Pier Amusement Co. v. Unemployment Comp. Comm., 127 N. J. L. 154, 21 A. (2d) 767 (1911); Superior Life, Health and Accident Ins. Co. v. Board of Rev., 127 N. J. L. 537, 23 A. (2d) S06 (1942); Electrolux Corp. v. Board of Rev., 129 N. J. L. 154, 28 A. (2d) 207 (1942).

48. Singer Sewing Machine Co. v. State Unemployment Comp. Comm., 167 Ore. 142, 103 P. (2d) 708 (1910), aff'd on reh'g, 167 Ore. 158, 116 P. (2d) 744 (1941); Rahoutis v. Unemployment Comp. Comm., 171 Ore. 93, 136 P. (2d) 426 (1943); Journal Publishing Co. v. State Unemployment Comp. Comm., 155 P. (2d) 570 (Ore. Sup. Ct. 1945).

49. See note 40 supra.

50. Life and Casualty Ins. Co. v. Unemployment Comp. Comm., 178 Va. 46, 16 S. E. (2d) 357 (1941); Unemployment Comp. Comm., v. Harvey, 179 Va. 202, 18 S. E. (2d) 390 (1942); Unemployment Comp. Comm. v. Collins, 1S2 Va. 426, 29 S. E. (2d) 383 (1944).

51. McDermott v. State, 196 Wash. 261, 82 P. (2d) 568 (1938), in which Department One of the court held the statutory definition broader than the common law master and servant relation, was in that respect not followed by Department Two in Washington Recorder Pub. Co. v. Ernst, 199 Wash. 176, 91 P. (2d) 718 (1939), diseussed infro. The 3CEDermoll case view, however, was followed by subsequent decisions in Matter of Farwest Taxi Service, Inc., 9 Wash. (2d) 134, 115 P. (2d) 16! (1941); Mulhausen v. Bates, 9 Wash. (2d) 264, 114 P. (2d) 995 (1941); Matter of Foy, 10 Wash. (2d) 317, 116 P. (2d) 545 (1941); Sound Cities Gas \& Oil Co., Inc. v. Ryan, 13 Wash. (2d) 457, 125 P. (2d) 246 (1942); State v. Goessman, 13 Wash. (2d) 598, 126 P. (2d) 201 (1942); Matter of Employess of Hillman Investment Co., 15 Wash. (2d) 452, 131 P. (2d) 160 (1942); Unemployment Comp. Dep't v. Hunt, 17 Wash. (2d) 22S, 135 P. (2d) 89 (1943).

52. Moorman MIfg. Co. v. Industrial Comm., 241 Wis. 200, 5 N. W. (2d) 743 (1942), clarifying the earlier decision in Wisconsin Bridge \& Iron Co. v. Industrial Comm., 233 Wis. 467, 290 N. W. 199 (1940); AIaloney v. Industrial Comm., 242 Wis. 165, 9 N. W. (2d) 623 (1943). For critical analysis of Wisconsin Bridge \& Iron Co. case see note [1911] WIS. L. REV. 269.

53. Industrial Comm. v. Northwestern Mutual Life Ins. Co., 103 Colo. 550, 83 P. (2d) 560 (1939); Murphy v. Daumit, 387 IIl. 406, 56 N. E. (2d) 800 (1944); Sound Cities Gas \& Oil Co., Inc. v. Ryan, 13 Wash. (2d) 457,125 P. (2d) 246 (1942). 
control over "details" or "physical performance" of services would still be considered "general control" remains unclear. Neither of the alternatives of the second test, relating to whether the services are performed outside the usual course of the principal's business or out side all of his places of business, has received very great discussion. In a recent decision of the Utah court, however, the decision of the administrative agency under review, that a "name" dance band and "specialty entertainers" engaged by a hotel were in "employment," was based solely on a finding that the second test was not met. ${ }^{.4}$ The court held that neither alternative was satisfied, since it was usual and customary for the hotel to furnish such entertainment and since the services were performed in the hotel company's place of business. A number of courts have held that the place at which a salesman collects insurance "debits" or makes sales calls is the place of business of the principal. ${ }^{55}$

- The third test has been given very great significance by most of the courts which have recognized the departure of the statutory definition from the common-law test. It has been held that to meet the test it is necessary to show that the person performing services is established in the business of performing like services independent of whatever connection he may have with the principal ${ }^{56}$ and that he must have a proprietary interest in such business, something in which he has a right of continuity, which he can sell or give away, and which is not subject to cancellation or destruction upon severance of the relationship with the principal..$^{57}$

54. Utah Hotel Co. v. Utah Industrial Comm., 151 P. (2d) 467 (Utah 1944).

55. Life and Casualty Ins. Co. v. Unemployment Comp. Comm., 178 Va. 46, 16 S. E. (2d) 357 (1941); Superior Life, Health and Accident Ins. Co. v. Board of Rev., 127 N. J. L. 537, 23 A. (2d) 806 (1942); Unemployment Comp. Comm. v. Collins, 182 Va. 426, 29 S. E. (2d) 388 (1944); Babb \& Nolan v. Huiet, $67 \mathrm{Ga}$. App. 861, 21 S. E. (2d) 663 (1942). This view was criticized in Washington Recorder Publishing Co. v. Ernst, 199 Wash. 176, 91 P. (2d) 718 (1939). In Northern Oil Co. v. Industrial Comm., 104 Utah 353, 140 P. (2d) 329 (1943), the Utah court seems to have correctly applied this alternative, holding that the places at which the salesmen solicited sales of securities were not places of business of the principal, but that the alternative remained unsatisfied because the sales were consummated at the principal's offices to which the salesmen brought customers. See John Gabel Mifg. Co. v. Murphy, 62 N. E. (2d) 401 (Ill. 1945), in which the Illinois court held persons servicing "juke boxes" performed such services at the principal's place of business, since the principal and the owner of the premises at which the machine was placed shared collections.

-56. Industrial Comm. v. Northwestern Mutual Life Ins. Co., 103 Colo. 550, 88 P. (2d) 560 (1939).

57. Life and Casualty Ins. Co. v. Unemployment Comp. Comm., 178 Va. 46, 16 S. E. (2d) 357 (1941). See also Unemployment Comp. Comm. v. Collins, 182 Va. 426, 29 S. E. (2d) 388 (1944); Fuller Brush Co. v. Industrial Comm., 99 Utah 97, 104 P. (2d) 201 (1940); Murphy v. Daumit, 387 IIl. 406, 56 N. E. (2d) 800 (1944). The fact that the alleged employee has other independent activities has been held immaterial, if with respect to the services in question he does not conduct an independent business. Northern Oil Co. v. Industrial Comm., 104 Utah 353, 140 P. (2d) 329 (1943). Some state statutes specifically so provide. See note 24 supra. 


\section{Minority View: "ABC" Definition Not Given Full Application.}

In a few states the courts have not given full scope to the " $\mathrm{ABC}$ " definition, either by holding that the definition itself does not extend coverage beyond the common-law master-servant relationship, or, to the same result, by applying the definition only to determine whether relationships which have been held to be common-law master-servant relationships shall nevertheless be excluded from coverage.

The former view, as to the " $\mathrm{A}$ " and " $\mathrm{C}$ " tests, was first expressed in 1939 by Department Two of the Washington Supreme Court in Wasizington Recorder Publishing Company v. Ernst.: The case involved the coverage of newspaper carriers, operating under the "Little Merchant Plan," which is in widespread use throughout the nation, whereby the carrier agrees to abide by rules prescribed by the publisher, to deliver promptly and regularly each day to designated subscribers, to collect from subscribers on a specified day at an established rate, to keep correct subscription lists on prescribed forms, to deliver free any complimentary copies, and not to handle any other newspaper. The difference between the subscriber price and the price charged the carrier by the publisher constitutes "compensation for delivery and collection."

Department Two of the Supreme Court, in a decision affirming the lower court which had reversed a determination of the administrative agency that the services were in employment, first observed that at the time of the adoption of the state unemployment compensation statute the weight of authority was to the effect that carriers operating under similar contracts were independent contractors. ${ }^{\text {ig }}$ Turning to the first and third tests of the statutory "employment definition," " 3 the court held that they

“. . . do not differ from the test employed at the common law and by this court in determination of the question whether the relationship is that of employee or independent contractor. In the Restatement of the Law of Agency, nine different items are recited as the principal elements to be considered in determining which relationship [employee or independent contractor] exists. In the enact-

58. 199 Wash. 176, 91 P. (2d) 718 (1939).

59. As to the cases cited for this proposition, in Bohanon v. MIcClatchy Pub. Co., 16 Cal. App. (2d) 188, 60 P. (2d) 510 (1936); Batt v. San Diego Sun Pub. Co., 21 Cal. App. (2d) 429,69 P. (2d) 216 (1937); and Fidelity \& Casualty Co. v. Industrial Accident Comm., 191 Cal. 404, 216 Pac. 575 (1923), the California courts required "entire," "complete," or "unqualified" control by the principal, which was a more strict common law test than had theretofore been applied by the Washington court; the narrow test of the common law relationship applied in the remaining case, Gall v. Detroit Journal Co., 191 Mich. 405, 158 N. W. 36 (1916), had been expressly rejected in an earlier Washington decision, Dishman v. Whitney, 121 Wash. 157, 209 Pac. 12 (1922). See note 63 infra.

60. The third test of the statute was stronger than the third test generally used, in that it required that the independently established business must be "of the eame nature as that involved in the contract of service." 
ment of the unemployment compensation statute, the legislature . . . picked out three elements to be considered. The legislature did not say, nor is the language capable of that interpretation, that each of those elements must exist one hundred per cent in order to establish the relationship of independent contractor. Surely, the legislature did not intend to establish a different rule than that which has heretofore been employed by this court. To hold otherwise, would be to, in effect, eliminate the relationship of independent contractor. It would be a violent presumption indeed to hold that that was the purpose of the legislature." 61

The court proceeded to analyze the " $A$ " and " $C$ " tests in terms of tort law. It reasoned, without apparent regard for the independent significance given each of the three tests in the statute, that since at common law the control test governed, the " $C$ " test of the statute must be considered a corollary of the " $A$ " test, and thus, in effect, that where one is not subject to control under common-law criteria the " $\mathrm{C}$ " test is satisfied. ${ }^{62}$

61. Washington Recorder Pub. Co. v. Ernst, 199 Wash. 176, 186-7, 91 P. (2d) 718, 724 (1939). In view of the clear provision of the statute that all services "shall be deemed to be employment subject to this Act unless and until it is shown," that all three of the prescribed tests are met, it is difficult indeed to understand the court's statement that the legislature did not say, and that the statute is not capable of the interpretation, that each of the tests must be wholly met. Nor does it seem inexplicable that the legislature may have intended to eliminate for the purposes of unemployment compensation coverage the fine distinctions involved in applying the independent contractor concept in tort law. At the time of this decision two courts had held that such was the obvious intention of their respective legislatures, the North Carolina Supreme Court in Unemployment Comp. Comm. v. Jefferson Standard Life Ins. Co., 215 N. C. 479, 2 S. E. (2d) 584 (1939), and the Colorado Supreme Court in Industrial Comm. v. Northwestern Mutual Life Ins. Co., 103 Colo. 550, 88 P. (2d) 560 (1939). The suggestion by the court that to permit coverage for unemployment compensation purposes of persons who may be "independent contractors" at common law would eliminate the relationship of independent contractor is clearly specious. The statute is applicable only to determining coverage for unemployment compensation purposcs.

62. It is difficult to understand how the carriers could be considered to be "customarily engaged in an independently established trade, occupation, profession or business of the same nature as that involved in the contract of service," in view of the fact that they wero not established and customarily engaged in the business of sale and distribution of newspapers independently of their connection with the publisher, that the arrangement forbade them from performing similar activities for any other publisher, and that they did not hold themselves out as engaged in an enterprise of their own which would survive termination of their relationship with this particular publisher. A dissenting judge pointed out that in an earlier unemployment compensation case, McDermott v. State, 196 Wash. 261, 82 P. (2d) 568 (1938), which was nowhere discussed on this point in the court's opinion, the court (Department One) had held the statutory definition was not an embodiment of commonlaw tests. He concluded that it was the obvious intention of the legislature "to prevent the evasions which could arise from the refined distinctions which so often attend those commonlaw concepts," and quoted without comment the following from the opinion of the North Carolina Supreme Court in Unemployment Comp. Comm. v. Jefferson Standard Life Ins. Co., 215 N. C. 479,2 S. E. (2d) 584 (1939) interpreting the "ABC" definition: 
Although the Washington Recorder decision was in effect overruled, ${ }^{63}$ it caused considerable difficulty in other states in sustaining the statutory definition in full vigor, and its reasoning was in fact followed by some courts.

Soon thereafter the effectiveness of the "ABC" definition was threatened by the decision of the Utah Supreme Court in Fuller Brtsil Company v. Industrial Commission. ${ }^{04}$ The case involved the coverage of so-called "dealers" of the Fuller Brush Company who were assigned specific territories, were supplied with sample brushes, and "purchased" goods from the company for cash or credit which they resold to purchasers by house-to-house canvassing at an advanced price suggested by the company. Unsold brushes could be returned to the company. The common attributes of a sales organization were present: a representative of the company in charge of sales in that district hired and

"The power of the General Assembly to broaden or restrict common law" concepts is widely recognized [citations] and is not here challenged. Although the extent of the area encompassed by some of the definition may cause surprisa, the duty of this court is to expound and to interpret the law as it is given to us, not to re-draft it along lines which may seem to us more conservative and more desirable. The economic and social evil of unemployment in its broad sweep frequently disregards man-made geographic and political boundaries; perhaps, it follows that former boundaries must be surrendered in seelsing a remedy for such an cvil. If new eocial evils produce, as counter-forces, new ideas of control of these evils, and such ideas are brought to us from the legislative forum, we must guard against falling victims to that suspicion which is born of the mere novelty of things."

Washington Recorder Pub. Co. v. Ernst, 199 Wash. 176, 197-S, 91 P. (2d) 718, 723 (1939). It is interesting to note that the Washington court in Milson v. Times Printing Co., 158 Wash. 95, 290 Pac. 691 (1930), involving substantially the same facts, had afirmed the judgment of the lower court which held the publisher liable for injuries aused a third parson by the negligence of its newspaper carrier. Yet in the instant case the court held that 35 a matter of law the carriers were independent contractors.

63. See cases cited supra note 51. The conflict between Departments One and Two of the Court, reflected in the $11 C D$ ermolt and Wrashinglon Recorder cases, was recolved by the court en banc in Matter of Foy, 10 Wash. (2d) 317, 116 P. (2d) 545 (1941). In the Sound Cities Gas \& Oil Co., Inc. v. Ryan, 13 Wash. (2d) 457, 461-5, 125 P. (2d) 246, 249 (19:2) the court en banc said:

"The opinions of this court, just cited, with the esception of Basling con Re. corder $P u b$. Co. \&. Errzst, supra, commit this court to the view that our unemployment compensation act, which is similar to those of the majority of the states where this form of social security obtains, does not confine tasible employment to the relation of master and servant. If the common law relationship of master and esr:ant was to obtain, the legislature would have so stated."

Relationships with newspaper carriers substantially similar to that in issue in the W"aslizmton Recorder case were subsequently held within the "ABC" definition in Salt Lalse Tribune Pub. Co. v. Industrial Comm., 99 Utah 259, 102 P. (2d) 307 (1940), and in Journal Pub. Co. v. State Unemployment Comp. Comm., 155 P. (2d) 570 (Ore. Sup. Ct. 1915). See also Matter of Scatola, 282 N. Y. 689, 26 N. E. (2d) $\$ 15$ (1940), and California Employment Comm. v, Los Angeles Downtown Shopping News Corp., 24 Cal. (2d) 421, 150 P. (2d) 186 (1914), each involving application of common-law criteria

64. 99 Utah 97, 104 P. (2d) 201 (1940). 
gave advice to dealers on the conduct of their sales activities, and "requested" progress reports from them; a sales manual suggesting the method of canvassing was provided and sales meetings were held daily; prizes and premiums were given for a good sales record; and a sales force bulletin was published by the company. The relationship was terminable at will.

The court observed that clause (1) of the definition of "employment" defines that word as "service . . . performed for wages or under any contract of hire," and concluded that a personal service relationship must be found to exist under clause (1), before it is inquired whether the relationship meets the "ABC" tests in clause (5) and is thereby excluded from "employment." Whether a personal service relationship exists depends, continued the court, on the following criterion:

". . . services are performed for another when performed under his supervision, direction and control, in the performance of the details of the work and in the use of the means employed; (Texas Co. v. Wheeless, 185 Miss. 799, 187 So. 880), when he has the right to hire (select the worker) and the right to fire (terminate the employment) and when the compensation, if any, accruing to the worker becomes a direct liability on the other party. But all of these are not always present, and if present they may not be evident on a casual examination." 65

Even if a particular relationship constitutes a personal service relationship, the court added, it is not "employment" unless it is for "wages," which is defined as "remuneration for personal services."

The court held that the dealers did not perform personal services for the company because they were not subject to control and direction by the company, ${ }^{66}$ although it seemed to concede that if a personal service relationship had existed, the " $C$ " exclusionary test would not have been met inasmuch as the dealers were not customarily engaged in an independently established business. Nor were the services rendered for wages, the court concluded, because the dealer received his remuneration not from the company but in the difference between the price charged him by the company and the price he collected from the customer.

In effect, while making no reference in this connection to the common-law master-servant relationship eo nomine, the court seems to have held as follows: Employment means all services for wages, i.e.,

65. Id. at 103, 104 P. (2d) at 203. The Mississippi case cited by the court involved unemployment compensation coverage under a statute which contains the words "cmployer" and "employee" without providing any statutory definition, as does the Utah statute, of the employment relationship.

66. The administrative tribunal had found that a service relationship existed, that although the " $\mathrm{A}$ " test was met, the " $\mathrm{C}$ " test was not, and therefore the services were not excluded from "employment." 
remuneration for personal services, unless the " $A B C$ " tests are met. Before the "ABC" tests are applied it must be found that there is a service relationship between the parties. A service relationship exists only where the relationship would constitute the master-servant relationship at common law, which is conceived in terms of the master's right to control the physical performance of services.

This rationale, as the Utah court later recognized, does riolence to the statutory definition. It seems quite proper to consider clause (1) to require that a service relationship exist before inquiry is directed to whether under clause (5) such service relationship is nevertheless excluded from "employment." But it is another matter to hold that "service relationship" means common-law master-servant relationship and, therefore, that the "ABC" tests are to be applied only to exclude from coverage services which have already been found to meet the test of the master-servant relationship. It would seem that a commonlaw master-servant relationship could not meet the three statutory tests, which the court elsewhere agreed are clearly broader than the common law, ${ }^{67}$ and perhaps not any one of them. If the decision were followed, clause (5) containing the "ABC" tests would never come into play. ${ }^{\text {ss }}$

The distortion of the statute by the rationale of the Utah Fuller Brush case was very well described by the Oregon Supreme Court in Singer Sewing Machine Company a. Unemployment Compensation Commission, in which the court refused to follow the position of the Utah court:

"[To hold] that the relation of master and servant must first be shown before services performed by an individual for remuneration shall be deemed to be employment subject to the unemployment compensation act ... interpolates a clause which is not in the statute, namely: where the common law relationship of master and servant is shown to exist. . . . The writer thinks that if the Oregon legislature had deemed the common law relationship of master

67. See note 40 supra.

68. There was a vigorous and cogent dissent by Justice Wolfe, Fuller Brush Co. v. Industrial Comm., 99 Utah 97, 107, 10\$ P. (2d) 201, 205 (1940). The decision was in clear conflict with prior decisions of the same court; see cases cited supra note 40 ; in Creameries of America v. Industrial Comm., 98 Utah 571, 580, 583, 102 P. (2d) 300, 304, 305 (1910) the court had expressly rejected the contention that the master-servant relationship must exist before the "ABC" test becomes applicable, had interpreted the service relationship as including "generally any act performed for the benefit of another under some arrangement or agreement whereby such act was to have been performed," and had emphasized that the way "service" is used in the Act "indicates an intention on the part of the legislature to use the term in its broad general sense." Cf. Schomp v. Fuller Brush Co., 124 N. J. L. 487, 12 A. (2d) 702 (1910), involving the same relationship, in which the New Jeresy court gave full application to the "ABC" definition, and moreover found such a comprehensive control exercised over the "dealers" as to indicate that a common-law master-servant relationship existed. 
and servant an essential prerequisite to a participation in the protection and benefits of the act in question that honorable body would have plainly said so as many other legislative bodies have." 69

The Utah court in a subsequent case ${ }^{70}$ stated that it had not really meant what it had seemed to say, and in novel fashion allayed any misunderstanding by quoting and rewriting the troublesome portions of its Fuller Brush opinion. The court held specifically that the "ABC" definition does extend coverage beyond the common-law masterservant relationship, and that a service relationship may exist even where the principal does not have a right to control the physical performance of services. But, just as the Washington Recorder case was followed by other courts in achieving restrictive interpretations of the "ABC" definition which persisted after the Washington court had in effect overruled that case, so too the Fuller Brush case was used to the same end, ${ }^{71}$ even after it had been rewritten. ${ }^{72}$

The decisions in other states which do not give full application to the statutory definition follow the pattern of the Washington Recorder case, the Fuller Brush case, or a combination of both. The Nebraska court in Hill Hotel Company v. Kinney ${ }^{73}$ considered the argument plausible that "the legislature had power to change the common law adopted in this state and make legislative definitions applicable to new

69. 167 Ore. $158,163-4,116$ P. (2d) 744, 746 (1941), aff'g on reh'g, 167 Ore. 142, 103 P. (2d) 708 (1940).

170. Singer Sewing Machine Co. v. Industrial Comm., 104 Utah 175, 134 P. (2d) 479 (1942).

71. In A. J. Meyer \& Co. v. Unemployment Comp. Comm., 348 Mo. 147, 152 S. W. (2d) 184 (1941) the Missouri court followed the Fuller Brush decision and construed the "ABC" definition as the equivalent of the common-law relationship. The Utah court in Singer Sewing Machine Co. v. Industrial Comm., 104 Utah 175, 193, 134 P. (2d) 479, 487 (1943), aff'd on reh'g, 104 Utah 196, 141 P. (2d) 694 (1943), observed that if the Missouri court "interpreted the Fuller opinion to hold that we confined the Act to the master and servant relationship, or therein made any pronouncements with respect to independent contractors, it misconceived and misinterpreted that opinion."

72. Before leaving the Washington Recorder and Filller Brtish cases it should be noted that in each decision the court characterized the relationship involved as a vendor-vendee relationship; the Utah court considered such a relationship to preclude existence of a service relationship. This question was recently discussed at length in Journal Pub. Co. v. State Unemployment Comp. Comm., 155 P. (2d) 570 (Ore. 1945), in which the Oregon court observed that although the passage of the goods (newspapers in that case) between the parties was in the form of a sale, the important aspect of the matter is that the "vendee" was obligated by contract to dispose of them in a certain manner, by daily sale and delivery to a list of subscribers. The court characterized "service" essentially as aiding the principal in the regular conduct of its business. By and large the courts have not had any difficulty in piercing the characterization given a relationship by the parties-whether sale, lease, consignment, etc.- -where its real character is one of continuous activity in an integral part of the principal's enterprise, without the economic freedom of action ordinarily accompany. ing a true sale or lease.

73. 138 Neb. 760, 295 N. W. 397 (1940). 
enactments" and "that such power was exercised in the present instance" but concluded that the reasoning of the Wrashinglon Recorder case was more sound. ${ }^{74}$ The court observed that the legislature had adopted the common-law definition of independent contractor in the workmen's compensation law, and that since in both that law and in the unemployment compensation law "the lawmakers legislated on labor problems ... it should not be held without sound reasons that they intended to vary the status of independent contractors under the two intimately related statutes." 75 Therefore, the court followed common-law rules and did not undertake to apply the statutory definition to the fact situation before it. ${ }^{\text {ic }}$ Similarly, in Unemployment Compensation Commission v. Mathew', " holding musicians not in "employment" of a hotel company, the Wyoming Supreme Court folloved the Washington Recorder case and concluded that the "ABC" definition was but a restatement of the common law. ${ }^{\text {is }}$

The Florida Supreme Court, in a puzzling decision in Gentile Bros. Company v. Florida Industrial Commission, 70 did not expressly refer at any point in its opinion to the three-test statutory provisions defining the employment relationship, but rather observed that the legislature did not express a positive intention to abrogate or enlarge upon the common-law master and servant relationship, which was "well recognized by our law and the courts of this State." $\mathfrak{m}$ The court cited the Wisconsin Bridge \& Iron Company and Washington Recorder cases

74. Id. at $761,295 \mathrm{~N}$. W. at 399.

75. Ioid.

76. The decision is criticized in Note (1942) 21 NEb. L. REv. 64.

77. 56 Wyo. 479 , 111 P. (2d) 111 (1941). Criticized in (1941) 90 U. of P.. L. REv. 229.

78. The court did however apply the statutory tests. In doing so, it is interesting to note, it found that the services of the musicians were outside the usual course of the hotel company's business (the first alternative of the " $\mathrm{B}$ " test), although musicians had teen employed by the company for services of the lind in question for at least three years preceding the trial. For opposite result see Utah Hotel Co. v. Industrial Comm., 151 P. (2d) 467 (Utah 1944).

The scope of the statutory definition was not clarified in a later decision, Tharp $v$. Unemployment Comp. Comm., 57 Wyo. 4S6, 121 P. (2d) 172 (1942), holding tarbers to ke employees on the basis of common law precedent.

The Nebraska and Wyoming courts have not been faced equarely with the question of the scope of the statutory definition since the modification of the I" aslinglon Recorder decision on which they so heavily relied. The uncertainty which they reflected in the Hill Hos! and Matheres decisions suggests that they might express a different view in the future.

79. $151 \mathrm{Fla} .857,10$ So. (2d) 568 (1942).

So. The court, apparently contemplating a novel sort of estoppel against the legialature, observed that "hundreds of thousands of dollars are paid out annuslly" by busineses of Florida on the basis of the common law independent contractor relationship.

The Florida law contains the common declaration of policy and also a provicion ( $\$ 443.20)$ that the Act "shall be liberally construed to accomplish its purpose . . . to provide through the accumulation of reserves for the payment of compensation to individuals with respact to their unemployment." 
as authority that the statutory definitions were merely declaratory of the common law; the Wisconsin case, however, had never stood for that proposition ${ }^{81}$ and the Washington Recorder case had been overruled as far as that proposition was concerned, and these facts had been brought to the attention of the Florida court. Subsequently in Florida Industrial Commission v. Peninsular Life Insurance Company, ${ }^{82}$ the court, in discussing the three-test definition, concluded:

"Neither the history of the a-b-c-provisions nor the accepted canons of construction support this contention ['that the a-b-c-provisions . . . supersede the common-law definition of employment']. It appears that these provisions were first contained in the Wisconsin Social Security Act and the Supreme Court of that state in Wisconsin Bridge and Iron Co. v. Ramsey . . . , applied the common law meaning to the words 'employee' and 'employer.' A great majority of the states have followed this interpretation and we think the very terms of the Florida Act make it mandatory."

Again in this case the brief of the Industrial Commission had pointed out that the Wisconsin court, in Moorman Manufacturing Company v. Industrial Commission, ${ }^{83}$ had already clarified the Wisconsin Bridge \& Iron Company opinion and had treated the three-test provision as a statutory definition distinct from the common-law test. The court's description of the position taken by "a great majority of the states" was clearly erroneous.

The Tennessee Supreme Court, on the other hand, in Texas Company v. Bryant, ${ }^{84}$ followed the reasoning of the Utah court in the Fuller Brush case, and held that the "ABC" definition is to be applied to determine whether the relationship is excluded from employment only after it has been determined by master-servant criteria that the relationship is otherwise included. ${ }^{85}$ This presents an interesting contrast with the holding of the same court with respect to workmen's compensation coverage that where a person performs services for another there is a presumption that he is an employee and the burden is upon the principal to show otherwise. ${ }^{86}$ Subsequent decisions of the Tennessee court have left unclear the meaning of the statutory provisions. In Guaranty Mortgage Company v. Bryant, ${ }^{87}$ the court, on the authority of the Fuller

81. See note 52 stupra, and note 83 infra.

82. 152 Fla. 55, 58, 10 So. (2d) 793,794 (1942); see companion cases, Industrial Comm. v. Independent Life and Accident Ins. Co., $152 \mathrm{Fla} .58,10$ So. (2d) 794 (1942) and Industrial Comm. v. Gulf Life Ins. Co., 152 Fla. 59, 10 So. (2d) 795 (1942).

83. 241 Wis. 200,5 N. W. (2d) 743 (1942).

84. 178 Tenn. 1, 152 S. W. (2d) 627 (1941), reh'g denied, 178 Tenn. 680, 163 S. W. (2d) 71 (1942).

85. The court adopted the analysis of Fuller Brush Co. v. Industrial Comm., 99 Utah 97, 104 P. (2d) 201 (1940) in haec verba although the Utah decision was not cited.

86. Carter v. Hodges, 175 Tenn. 96, 132 S. W. (2d) 211 (1939).

.87. 179 Tenn. 579, 168 S. W. (2d) 182 (1943). 
Brush case, held that real estate salesmen on a commission basis did not render services for wages. ${ }^{83}$ In National Optical Stores Company v. Bryant, ${ }^{59}$ an eye expert engaged on a full-time basis with a guaranteed income was held to be in employment. The court concluded that the individual rendered services for wages, and distinguished the Guaranty Mortgage Company case on that basis, but it did not state why it reached that conclusion. The court then proceeded to apply the "ABC" tests, but it treated them as though they were three disjunctive tests, whereas they are clearly conjunctive, and failed to distinguish clearly the statutory definition from common-law tests. And in Wolfe v. Bryant ${ }^{\circ 3}$ the court again treating the three tests as disjunctive, held certain services not in "employment" because the " $C$ " test was met; the " $A$ " and " $B$ " tests were neither referred to nor discussed. Thus, although in more recent decisions the court has given much less prominence than formerly to the rationale of the Fuller Brush case regarding proof of the service relationship, it remains uncertain whether the court will in the future give full significance to the " $\mathrm{ABC}$ " tests.

The Ohio Supreme Court has also taken the view that the "ABC" tests are applied to determine whether a wage earner, who is a servant at common law, is nevertheless excluded. ${ }^{91}$ In a series of cases involv-

8s. The court, following the Missouri court in the A. J. Mrger cass, held the statute to be a taxing measure and subject to strict construction. Similarly in Wolfe v. Bryant, 181 S. W. (2d) $3 \$ 3$ (Tenn. Sup. Ct. 19:4).

S9. 181 S. W. (2d) 139 (Tenn. Sup. Ct. 1944).

90. 181 S. W. (2d) 343 (Tenn. Sup. Ct. 1944).

91. Commercial Motor Freight, Inc. v. Ebright, 143 Ohio St. 127, 54 N. E. (24) 297 (1944), reversing the position taken by the Ohio Court of Appeals in the eame case, $51 \mathrm{X}$. E. (2d) 293 (1943), and in State v. Iden, 71 Ohio App. 65, 47 N. E. (2d) 907 (1942).

The Ohio statute is more susceptible of such a construction than statutes of other states. The paragraph containing the "ABC" test [sub-paragraph (D) of paragraph (c)] is sulordinated to the paragraph containing the broad introductory definition of employnent [paragraph (C)] rather than being a coürdinate paragraph as in the statutes of other ctates. Moreover, paragraph (c) of the Ohio definition provides that "employment" means rarvice performed "for remuneration under any contract of hire," rather than for remuneration or under any contract of hire as is the case generally in statutes containing the "ABC" tests. The term "contract of hire" is also used in the Ohio Worlimen's Compeneation Law and has been interpreted in terms of master-servant criteria. Coviello v. Industrial Comm., 129 Ohio St. 589, 196 N. E. 661 (1935). The court, hovever, in the Comsncrial Afolor Frcight case did not rest on this distinction but rather on the subordination of sub-paragraph (D to paragraph (c). The decision does not satisfactorily discuss the import of sub-paragraph (D) which provides that services for remuneration shall be deemed to be employment unles 3 and until it is shown that the " $\mathrm{ABC}$ " tests are met.

Sub-paragraph (E) of paragraph (c) specifically excludes from coverage certain services, indicating that it rather than sub-paragraph $(D)$ is the exclusionary provicion. Claus? (7) of sub-paragraph (E) excludes "service performed by an individual . . . vho is compensated on a commission basis, and who . . . is master of his own time and efforts, and whose remuneration is wholly dependent on the amount of effort he chooses to expend." Applied in Bowman v. Atkinson, 136 Ohio St. 495, 26 N. E. (2d) 798 (1940), and Hauswirth v. Board of Review, 69 Ohio App. 79, 43 N. E. (2d) 240 (1941). 
ing claims for unemployment benefits, the Superior Court of Pennsylvania has seemed to view the "ABC" tests as exclusionary in nature."2 But since the Pennsylvania case law seems to provide substantially as broad a view of the common-law relationship as is provided by full application of the "ABC" definition, the adherence of the Superior Court to common-law precedent seems to have worked little harm..$^{93}$ Although drawing from the rationale both of the Washington Recorder and Fuller Brush decisions, the opinion of the Missouri Supreme Court in A. J. Meyer \& Company v. Unemployment Compensation Commission, ${ }^{94}$ is noteworthy for the obvious aversion of the court to

92. Leinbach Co. v. Unemployment Comp. Board of Review, 146 Pa. Super. 237, $22 \mathrm{~A}$. (2d) 57 (1941). See Palumbo v. Unemployment Comp. Board of Review, 148 Pa. Super. 289, 25 A. (2d) 80 (1942); American Writing Machine Co. v. Unemployment Comp. Board of Review, $148 \mathrm{~Pa}$. Super. 299, 25 A. (2d) 85 (1942); Superior Life, Health \& Accident Ins. Co. v. Unemployment Comp. Board of Review, 148 Pa. Super. 307, 25 A. (2d) 88 (1942).

93. Under the Pennsylvania Act the Superior Court, the court of general appellate jurisdiction, hears appeals from benefit decisions (sec. 510), while an inferior court, the Court of Common Pleas for Dauphin County, considers appeals by employers from assessment of contributions (sec. 304) and actions by the Commonwealth to collect contributions, The Superior Court has not reviewed decisions of the latter court. The Court of Common Pleas has seemed to take a narrower view of the employment relationship, apparently influenced in large measure by the fact that it is concerned with contribution liability. Department of Labor and Industry v. Freeman, 55 Dauph. Cy. 112 (1944). Commonwealth v. Wysocki, 55 Dauph. Cy. 413 (1944). It has distinguished Superior Court decisions holding claimants to be employees on the ground that they involved claims for benefits rather than for relief from assessment of contributions. The Court of Common Pleas, however, cites the Superior Court decisions as support when it holds that an employment relationship exists. Commonwealth v. Wertz, 53 Dauph. Cy. 353 (1943); Commonwealth v. Marie Gas \& Oil Co., 56 Dauph. Cy. 200 (1944); Commonwealth v. MeNelly, 56 Dauph. Cy. 95 (1944); Commonwealth v. Cooper, 55 Dauph. Cy. 528 (1944); Walters v. Commonwealth, 56 Dauph. Cy. 245 (1945). Moreover, the Court of Common Pleas makes its own findings of fact on the contributions issue while in cases before the Superior Court the findings of fact of the administrative tribunal are conclusive if supported by substantial evidence. In setting forth the applicability of the " $\mathrm{ABC}$ " definition, the Court of Common Pleas, long after the Washington Recorder case was overruled in that respect by the Washington Supreme Court, quoted from that decision and approved the statement that the "ABC" definition is but a restatement of the master-servant relationship. Further, without referring to the broad declaration of policy contained in the Pennsylvania law (\$3) proclaiming the Act to be in the exercise of the police power for the public good and general welfare of the Commonwealth, the court has indicated that in so far as contribution liability is concerned, the unemployment compensation provisions may be less liberally construed than the Workmen's Compensation Act which the legislature has directed be liberally construed. This position, taken in Department of Labor and Industry v. Freeman, supra, is at variance with the viow expressed by the same court in Commonwealth v. Wertz, supra. Even considering contributions as "taxes," Commonwealth v. Perkins, $342 \mathrm{~Pa}$. 529, 21 A. (2d) 45 (1941), the court should not ignore the fact that the contribution and benefit sections of the law relate to a single definition of covered employment. It may be hoped that the divergence of attitude between this court and the Superior Court will be resolved by the Superior Court or by a definitive decision of the Pennsylvania Supreme Court.

94. 348 Mo. 147, 152 S. W. (2d) 184 (1941). The decision was by Division One; subsequently a petition for certification to the court en banc was denied. 
the criterion of coverage prescribed by the legislature. Reversing the administrative agency and the lower court, the court held that, as a matter of law, the claimant, a commission real-estate salesman, was not entitled to unemployment insurance benefits because he was not in "employment." 95 The court avoided application of the statutory definition by ignoring it. The court first observed that the title of the Unemployment Compensation Act provides that its purpose is to establish a system of unemployment insurance. It then noted that a Missouri statute provides that "words and phrases [of a statute] shall be taken in their plain or ordinary and usual sense" unless such would be plainly repugnant to the intent of the legislature, or of the context.s Therefore, the court consulted Webster's New International Dictionary for the plain, ordinary, and usual meaning of "unemployment" and noted that it meant "state of being not employed." The court consulted the same authority for the meaning of the words "employ," "employer," and "employee." The last was defined as "one . . . in . the service of another." The court found that it had said in a previous decision ${ }^{97}$ that the word "employ," when associated with the idea of service, "implies control by the employer over the means and manner of doing the work." The court then concluded:

"We do not think that it would be plainly repugnant to the intent of the Legislature or of the context to say that the terms, znnemployment, employment, employer, and employee are used in our Unemployment Compensation Act in their plain or ordinary and usual sense,' and so considered, these terms would be in harmony with the definition of employment as given in the act."

At no point in the opinion does the court look for guidance to the statutory definition of the word "employment," with which it is concerned. The court decides in effect that when the legislature specincally defines a term for particular purposes within an act, the meaning is to be found not in that definition but in the dictionary. It does so by adopting the remarkable tactic of submerging the word it is concerned with, "employment," in a sea of other words and then consulting Webster as to the meaning of them all. Not only is the word "employment" specifically defined in the statute, but the words "unemployment" and "employer", for the meaning of which the court consulted

95. In Babb \& Nolan v. Huiet, 67 Ga. App. \$61, 21 S. E. (2d) 663 (1912) the Grorgia court gave the "ABC" definition broad application in a case involving real estate ealemen operating in substantially the same relationship as in the A.J. AIcjar caca. Similarly, Rahoutis v. Unemployment Comp. Comm., 171 Ore. 93, 136 P. (2d) 426 (1943).

96. Mo. Rev. Stat. ANN. (1939) $\$ 655$.

97. Stein v. Battenfield Oil \& Grease Co., 327 M1o. 804, 39 S. W. (2d) 345 (1931), in which the statute contained the term "employed" without giving it a spscific statutory" definition. 
Webster, are also specifically defined in the statute for the purposes of the statute. ${ }^{98}$

Two other points raised by the court in the A.J. Meyer case deserve mention. Observing that the Unemployment Compensation Act includes a taxing statute, inasmuch, as the unemployment compensation fund from which unemployed persons derive benefit payments is made up of moneys contributed by employers pursuant to the act, the court concluded that it should be strictly construed. It would seem that a contrary conclusion is indicated by the declaration of policy of the act to which the court did not refer, and which emphasizes the remedial nature of the law.99 The court overlooked the fact that the coverage

98. This approach seems more strange when as in this case, the court makes no effort to ascertain whether the dictionary definition, which it fashions into the common-law control criterion, is plainly repugnant to the intent of the legislature as expressed in statutory definitions.

The court looked for support for its conclusion in the fact that in the sections of the act which determine the composition of the Unemployment Compensation Commission, the advisory council, and the appeals tribunal, it is provided that certain of the members shall be classified as representatives of "employers" or of "employees." The court concluded from that: "It is quite clear . . . that the terms employer and employce as [there] used . . . are used in their ordinary and usual sense." The opinion does not explain how this justified "giving a plain or ordinary meaning" to "employment" which was defined in the statute. Nor did the court note that in none of the sections of the law providing for contributions by "employers" or for the payment of benefits to individuals in "employment" is the word "employee" used. In those sections, at each point at which it was necessary, the legislature sedulously avoided the use of undefined terms, and used the terms "individual in employment by an employer," "employment" and "employer" having been given specific statutory definitions. The court apparently believed that its opinion was well supported by the interpretations of the "ABC" definition by five other courts: Hill Hotel Co. v. Kinney, 138 Neb. 760, 295 N. W. 397 (1940); Fuller Brush Co. v. Industrial Comm., 99 Utah 97, 104 P. (2d) 201 (1940); Washington Recorder Pub. Co. v. Ernst, 199 Wash. 176, 91 P. (2) 718 (1939); Wisconsin Bridge \& Iron Co. v. Ramsey, 233 Wis. 467, 290 N. W. 199 (1940); Unemploy. ment Comp. Comm. v. Mathews, 56 Wyo. 479, 111 P. (2d) 111 (1941). The Wisconsin, Washington, and Utah courts have subsequently clearly stated that the "ABC" provisions in their respective statutes are broad in effect and not restricted to common law concepts.

In subsequent decisions the Missouri Supreme Court has not been faced squarely with this question, the cases involving primarily the question whether persons who were clearly employees of someone, were employees of one party rather than another. Hartwig-Dischinger Realty Co. v. Unemployment Comp. Comm., 350 Mo. 690, 168 S. W. (2d) 78 (1943) (holding janitor an employee of real estate management company, not of owner); Trianon Hotel Co. v. Keitel, 350 Mo. 1041, 169 S. W. (2d) 891 (1943) (holding waiter an employee of hotel, not of union hiring agent); Atkisson v. Murphy, 352 Mo. 644, 179 S. W. (2d) 27 (1944). However, in the most recent decision, Atkisson $v$. Murphy, supra, with respect to the question whether the manager-lessee of a hotel coffee shop (in which the employces in question worked) was an employee of the hotel company, the court, in sustaining the ad. ministrative tribunal's decision that an employment relationship existed, again entirely ignored the statutory definition of employment and discussed the question solely in terms of the master-servant control criteria.

99. The declaration of policy operative at the time of the decision in the instant case is cited at note 34 supra. Subsequent to the decision this section was amended, the following phrase being added: "This law shall be liberally construed. . . ." 
definitions of the statute apply for benefits as well as contribution purposes and that, indeed, the sole issue was whether an unemployed claimant was entitled to receive unemployment benefits. It would seem that the rule of strict construction applied to general revenue measures should not apply when the exaction is but an incident of the broad remedial purposes of the act, especially when the same definition controls the benefit feature. ${ }^{100}$ Even less warrant is there for the use of the rule to strike down, rather than construe, an express statutory definition.

The court was apparently influenced also by the fact that the federal act imposing an unemployment tax upon employers defined employment as "service . . . by an employee for his employer," ${ }^{101}$ and that the Bureau of Internal Revenue had held in an ex parte ruling issued to the employer that the tax was inapplicable to the services of the claimant. ${ }^{102}$ But if the Missouri legislature did not intend to provide a

100. Contrast the following remarls of Judge Pratt in Logan-Cache Knitting Mills $v$. Industrial Comm., 99 Utah 1, 26-7, 102 P. (2d) 495, 507 (1940), regarding the Utah Unemployment Compensation Law: "In determining the purpose of an act of the Legiclature we should consider it as a unit. It is not under the police power in one breath, and under the revenue power in the next, as the eye shifts from section to section. We chould asl: ouraglves what led to its passage. Was it the need of additional money, or vas it come other purpose such as the eradication or restriction of an evil? I am digging a ditch. To do 50 , I bought a shovel. Was my purpose in so acting merely the desire for the shovel? It might be humorous, but it is hardly sensible to say that I am going to dig the ditch as an excuse to get the chovel. Are we to say, then, that all these provisions referring to the public good and weliare, the employment stabilization, the reduction and prevention of unemployment . . a are meraly creatures conceived as an excuse to raise revenue? It does not sound rcasonable. To me, there is no question but that this act was passed under the police pover of the state; and the compensation fund is merely the shovel used to dig the ditch. It is merely incidental to the purpose; the desire for it is not the purpose. . . . This court is on resord . . as recognizing that because an act includes sections of a revenue chareter, it does not follow that the act must have been passed under the revenue powers of the state." Soe cimilarly Buell v. Danaher, 127 Conn. 606, 18 A. (2d) 697 (1911); Young v. Bureau of Unemployment Comp., 63 Ga. App. 130, 10 S. E. (2d) 412 (1910); Mlaine Comm. v. Androscoggin, 137 Me. 154, 16 A. (2d) 252 (19:0); Singer Sewing Machine Co. v. State Unemployment Comp. Comm., 167 Ore. 142, 103 P. (2d) 708 (1940), afr'd on rel'g, 167 Ore. 158, 116 P. (2d) 74t (1911). In Maltz v. Jackoway-Katz Cap Co., 336 Mo. 1000, 82 S. IT. (2d) 909 (1935) the same Division of the Supreme Court, in holding a salesman to be an "employee" under the state Workmen's Compensation Act, referred to the "well linown practice of this court ... to apply sedulously the rule of liberal construction. Quite naturally and concistently we have no disposition to depart from that rule. ..." Id. at 1004, 82 S. IV. (2d) at 911.

101. INT. REv. CODE $\$ 1607$ (c) (1939).

102. The court observed that although the Missouri act "is not circumserited by the federal act," the "federal act is undoubtedly the bacliground of prectically all of the State Unemployment Compensation Acts." A. J. Meyer \& Company v. Unemployment Comp. Comm., 348 Mo. 147, 161, 152 S. W. (2d) 184, 190 (1941). See Commercial Motor Freigut, Inc. v. Ebright, 143 Ohio St. 127, 138, 54 N. E. (2d) 297, 302 (1914); Gentile Bros. Co. v. Florida Industrial Comm., 151 Fla. $857,862,10$ So. (2d) 568, 570 (19-2). Sae United States v. Vogue, Inc., 145 F. (2d) 609 (C. C. A. 4th, 1914), and Grace v. Mlogruder, 148 F. (2d) 679 (App. D. C. 1945), holding federal Unemployment Tax Act primarily remedial and its taxing phase secondary and incidental. 
broader test of coverage than the federal statute, there would seem to have been little purpose in prescribing the " $A B C$ " tests which contrast so sharply with the federal definition, and in requiring a showing that all three tests are met in order to establish that the statutory relationship does not exist.

\section{JUDiCIAI INTERPRETATION OF STATUTES NOT USING "ABC" DeFinition}

In states whose unemployment compensation statutes do not contain the " $\mathrm{ABC}$ " definition, the courts vary in the scope given the employment relationship. The Kentucky and Mississippi Supreme Courts have held statutes which contain no express reference to the commonlaw master and servant relationship to be restricted to that relationship. ${ }^{103}$ The Kentucky Court of Appeals, in a case holding bulk station operators who received petroleum products on a consignment basis not in employment, concluded that the words "employer" and "employee" must be considered to have been used in their ordinary sense, the master and servant relationship. ${ }^{104}$ Although the court noted that the act itself provided that "it shall be liberally construed to accomplish the purposes thereof," the court concluded that inasmuch as it involved the collection of contributions from employers it should be strictly construed as a taxing statute. ${ }^{105}$ The Mississippi Supreme Court followed the same reasoning in two cases involving bulk station operators; ${ }^{106}$ in the latter of the two cases, in which the relationship was considered "near the line of demarcation," the court resolved the doubt in "favor of the taxpayer and against the taxing power." Although in both cases the court with a refreshing realism observed that the operators "are capitalists, investors, and employers instead of men whose services are to be had for hire," it is doubtful, considering the emphasis given the applicability of the master-servant relationship criteria, that

103. Kentucky: Barnes v. Indian Refining Co., $280 \mathrm{Ky} .811,134$ S. W. (2d) 620 (1939); Commonwealth v. Potts, $295 \mathrm{Ky} .724,175 \mathrm{~S}$. W. (2d) 515 (1943); Radley v. Commonwealth, 297 Ky. 830, 181 S. W. (2d) 417 (1944). Mississippi: Texas Co. v. Wheeless, 185 Miss. 799, 187 So. 880 (1939); American Oil Co. v. Wheeless, 185 Miss. 521, 187 So. 889 (1939). The Mississippi statute was amended in 1940 to provide expressly that the employment relationship "shall be determined in accordance with the principles of the common law governing the relation of master and servant." Subsequently in North American Ins. Co. v. Unemployment Comp. Comm., 12 So. (2d) 925 (Miss. 1943), the court without opinion affirmed the decision of the administrative tribunal, which had been affirmed by the lower court, that the insurance agent in question was "a servant and not an independent contractor."

104. Barnes v. Indian Refining Co., $280 \mathrm{Ky} .811,134 \mathrm{~S}$. W. (2d) 620 (1939). The court cited Robinson v. Baltimore \& Ohio Railroad, 237 U. S. 84 (1915) in which the Supreme Court gave a similar construction to the coverage provision of the Federal Employers' Liability Act.

105. For criticism of this case see Note (1940) 29 KY. L. J. 82.

106. Texas Co. v. Wheeless, 185 Miss. 799, 187 So. 880 (1939) and American Oil Co، v. Wheeless, 185 Miss. 521, 187 So. 889 (1939). 
the court will extend the protection of the statute to those who are not "capitalists, investors, and employers" unless the strict common-law requirements are met.

In rather striking contrast to those decisions, the Connecticut Supreme Court of Errors, in construing a statutory definition of employment restricted to the common-law master and servant relationship, ${ }^{1 ; 5}$ has given the definition a rather wide scope, applying the broad test of "general control" developed in its workmen's compensation and tort decisions, and has held that the statute is not to be treated as a taxing statute and strictly construed but rather as clearly having a remedial purpose and, therefore, to be construed liberally in order to accomplish its purpose. Shortly after its decision in the first case before it involving unemployment insurance coverage, Northwestern Mutual Life Insurance Company v. Tone, ${ }^{103}$ in which the court held that insurance solicitors on a commission basis were not employees in the circumstances of the case, a decision which no longer has significant precedent value, ${ }^{109}$ the court in Jack and Jill, Inc. v. Tonc ${ }^{110}$ held ice cream route salesmen to be employees, looking to the substance of a contract designed to create a contrary appearance. The contract in question provided that the drivers were to "purchase" ice cream from the company at less than a fixed retail price and to sell the product on routes "loaned" for that purpose, and contained numerous provisions characterizing the driver as a "purchaser" and his activities as his "business." The court concluded that the company had a "general control" over the drivers' activities, stressing the power of the company to terminate the arrangement at will. ${ }^{111}$

107. The statute has been amended to provide that after October 1, 1943, cmployment means the relationship of "employer and employee" rather than "master and Esrvant."

108. 125 Conn. 183, 4 A. (2d) 610 (1939).

109. In this case the parties stipulated that no control was everciscd with resrect to the place and manner in which solicitation was conducted or as to the time devotcd to such activities by the agent. Although it seems from the stipulation that "the subject of Eale, the terms of sale, and the proceeds of sale remained in the control of the Company," which the court in Aisenberg v. C. F. Adams Co., 95 Conn. 419, 111 Atl. 591 (1920) had held constitutes a "general control," the court did not distinguish the Aiscnberg case eicept to obrerve that the factor of right to discharge, to which it had attached great importance in the Aiserberg case, is not necessarily conclusive. More recently in Buell v. Danaher, 127 Conn. 606 , 18 A. (2d) 697 (1941) the court distinguished the Norlhwestern Mitutul Life Insturance Co. case by noting that "that case was reserved for the advice of this court on an agrecd statement of facts while the case at bar resulted in quite a different finding made by a trial court after a contested hearing." Thus the Northurestern case now appears to be of very limited precedent value. The Colorado court in Industrial Comm. v. Northwestern Mutual Life Ins. Co., 103 Colo. 550, 564-5, 88 P. (2d) 560, 567 (1939), involving the same company and the same contract, observed that "a reading of the opinion in the Connecticut case will disclose that the Supreme Court there placed a rather strained construction on the relationship of master and servant as applied to its Unemployment Compensation Act."

110. 126 Conn. 114, 9 A. (2d) 497 (1939).

111. The court stated that the following language of Judge Cardozo in Matter of Gliclmi 
Subsequently, in Buell v. Danaher, ${ }^{112}$ the court more fully enunciated its view regarding the scope of the statute. The case involved the status of securities salesmen working on a commission basis. The court, holding that an employment relationship existed for purposes of the statute, stressed the fact that the principal furnished an office and facilities (except transportation) for the salesmen's work, had a right to designate what securities were to be sold, furnished the salesmen with information which they were expected to use as a part of their method of making sales, and retained the power of discharge. The court gave particular emphasis to the fact that the activities of the salesmen were in the furtherance of the principal's business and held as reasonable the trial court's conclusion that since the advancement of that business depends largely upon the method and manner in which the salesmen operate and since it is therefore highly essential for the principal to have a right to control the conduct of its salesmen in the doing of its business, it must be inferred that it is implicit in the contract of hiring that the principal does have that right.

v. Netherland Dairy Co., 254 N. Y. 60, 171 N. E. 906 (1930) (workmen's compensation case), "fits almost with precision . . . the case at bar": "The salesman has no discretion as to the manner of performance, or none that is substantial. He travels a prescribed route from which he may not deviate. If he fails to work it diligently, he knows that there will be an end of his employment as surely as if he were working for a stated wage. On the one side there is an intimacy of control and on the other a fullness of submission that imports the presence of a 'sovereign,' as the master, we are reminded, was sometimes called in the old books. . . . The contract is adroitly framed to suggest a different relation, but the difference is a semblance only, or so the triers of the facts might find." 126 Conn. 114, 120, $9 \mathrm{~A}$. (2d) 497,499 (1939).

112. 127 Conn. 606,18 A. (2d) 697 (1941). In this case the court rejected the view that the statute in question was a taxing statute requiring a strict construction, and adopted the view that it should be construed liberally.

The court reiterated its views expressed in a previous case, Beaverdale Memorial Park v. Danaher, 127 Conn. 175, 15 A. (2d) 17 (1940), that where the determination of the administrative agency is made ex parte and without notice, the aggrieved party is entitled to a full hearing in the trial court and that the trial court's determination as to the existence of an employment relationship, which is considered a question of fact, is controlling if not crroneous as a matter of law. Thus the Buell case makes it clear that the tribunal which gives a full hearing (whether it be the administrative agency or the trial court) may apply broad criteria in determining the existence of the employment relationship for unemployment compensation purposes, and gives considerable finality to the tribunal's determination of that question.

The position taken in the Buell case appears not to have been modified by the later decision of the court in Electrolux Corp. v. Danaher, 128 Conn. 342, 23 A. (2d) 135 (1941), in which the court found no error in the trial court's determination that vacuum cleaner salesmen working on a commission basis were not employees. The court was apparently disturbed by the similarity of the fact situations existing in the Jack and Jill and Butll cases to that in the instant case, and observed that "the determination of the status of individuals similarly situated is often difficult," but pointed out that in those cases, as in the instant case, the court would not say that the trial court erred as a matter of law. $I d$. at $351,23 \mathrm{~A}$. (2d) at 139. 
The decisions of the New York Court of Appeals do not present as consistent a pattern as might be hoped. ${ }^{113}$ Nevertheless the substantive content of the employment relationship is rather fully discussed in two decisions. ${ }^{114}$ In Matter of Morton ${ }^{115}$ the claimant for benefits was engaged by a company which manufactured and distributed, through salesmen such as claimant, a line of made-to-order ladies' undergarments. The saleswoman was compensated by the difference between the wholesale price charged her by the company and the retail price received by her from the customer. The agreement provided that the company would give her the benefit of its training in corsetry and salesmanship, which she agreed to practice and master; she agreed to furnish the company with the names and addresses of clients and to return samples and literature at the termination of the contract. The contract was to run for one year, but it could be terminated by the company if the saleswoman did not meet a sales quota. The Court of Appeals indicated that the concept evolved in tort law, which had been applied in cases arising under the New York Workmen's Compensation Law, was to be applied for unemployment compensation cases also. But like the Connecticut Supreme Court of Errors in Bucll :. Danaher, the New York Court of Appeals was impressed by the apparent necessity of the company, in order to carry on an effective sales program, to retain control over the general methods of salesmanship

113. A major determinant of its decisions appears to be the extent to which finality is accorded the fact findings of the Appeals Board, the tribunal for appeals from decicions of the administrative agency. The Court of Appeals has very strongly stated that such findings are conclusive if supported by substantial evidence. Matter of Morton, 2E\& $\mathcal{N}$. Y. 16\%, 30 N. E. (2d) 369 (1940); Matter of Electrolux Corp., 288 N. Y. 440,43 N. E. (2d, 490 (1942). Generally, where the Appellate Division affirms a dccision of the Appcals Beard holding that an employment relationship exists, the Court of Appeals afirms the Appullate Division decisions. Matter of Scatola, 282 N. Y. 6S9, 26 N. E. (2d) $\$ 15$ (1940) (newepapsr route carrier); Matter of Hanrahan, 287 N. Y. 559, 3S N. E. (2d) 227 (1911) (commision salesman); Matter of Wieder, 292 N. Y. 609, 55 N. E. (2d) 375 (1944); Matter of Dunne, 293 N. Y. 777, 58 N. E. (2d) 520 (19.4) (commission securities Ealesman); Mlatter of Apfel, 293 N. Y. 869,59 N. E. (2d) 451 (1944) (debit insurance collectors). But the Court of Appeals has quite frequently affirmed decisions of the Appellate Division which reveresd decisions of the Appeals Board holding that the employment relationship exists; it is not always clear in these cases, however, that the Appeals Board findings of fact are without substantial basis in evidence. See Matter of Levine, 283 N. X. 577, 27 N. E. (2d) 439 (1910) (commission salesman); Matter of Alford, 286 N. Y. 649, 36 N. E. (2d) 692 (1941) (c3me question and same employer as Levine case); Matter of Fidel Ass'n, 287 N. Y. 626, 39 న. E. (2d) 265 (1911) (commission securities salesmen); Matter of NuBone Co., $28 \mathrm{i} \mathrm{N.} \mathrm{Y.} \mathrm{716,}$ 39 N. E. (2d) 933 (1912) (corset salesmen operating similarly to those in Mlorton case); Matter of Barnaba Photographs Corp., 289 N. Y. 5S7, 43 N. E. (2d) 720 (1942) (frce lance photograph models); Matter of Wilson Sullivan Co., 389 N. Y. 110, 44 N. E. (2d) 387 (1912) (commission real estate salesmen).

114. In both cases the Court of Appeals reversed the Appellate Divicion and reinstatcd decisions of the Appeals Board which had held that the employment relationchip existed.

115. 284 N. Y. 167,30 N. E. (2d) 369 (1940). 
of its sales organization. The court emphasized that the company, and not the saleswoman, determined the method of corsetry and technique of salesmanship; this, concluded the court, was control over "the manner in which the work was to be done."

Again in Matter of Electrolux Corporation, ${ }^{116}$ the Court of Appeals was quick to look to the substance of an arrangement which was devised to create an appearance of a vendor-vendee relationship. ${ }^{117}$ The agreement specifically provided that while the company might make suggestions as to the methods of handling and selling its products, the "sales representative" could reject them if he wished and could devote such time to "his business" as he deemed advisable and conducive to best results. Salesmen were characterized as "independent-contractor consignees" and were advised that there was no limitation as to itineraries, volume of business, hours, selling methods, reports, collections, sales meetings, etc. The court at the outset emphasized that these salesmen constituted the company's sole distribution system, and that the company depended entirely on their canvassing to publicize and sell the vacuum cleaners it manufactured. "Consequently it is a little difficult to believe the protestations of respondent that it has not the slightest interest, or wish to interfere, in the selling activities of its representatives. ..."The court discussed the findings of the Appeals Board which indicated that the company operated its sales organization as an integral part of its business, maintaining an effective control, although in the form of suggestions, over the representatives' sales method. The court concluded that from the facts of operation, ". . . especially the right to terminate the contract upon short notice, it may be inferred that respondent has erected a system of moral sanctions and indirect compulsion which effectively regiment the activities of its representatives into a pattern desired by respondent of minute and detailed control. Under these circumstances, the expressed desires of the employer, though couched in terms of suggestion, are quite as effective as outright commands." 118

116. 288 N. Y. 440,43 N. E. (2d) 480 (1942).

117. The court considered the arrangement to have been "deliberately framed to take the ... [salesmen] . . out of the provisions of the unemployment compensation law."

118. 288 N. Y. $440,446,43$ N. E. (2d) 480,483 (1942). The California Supreme Court in California Employment Comm. v. Los Angeles Downtown Shopping News Corp., 24 Cal. (2d) 421, 150 P. (2d) 186 (1944) (newspaper carriers held employecs), although not expressly rejecting the contention of the Commission that the statutory definition of "employment" ("service . . . performed for wages or under any contract of hire . . .") includes not only common law employees but also "any relationship where the income of an individual is dependent upon the will of another," applied the control criterion which it had developed in respondeat superior and workmen's compensation cases; but the court emplaasized that the unemployment compensation act is "a remedial statute and must be con* strued for the purpose of accomplishing its objects." Subsequent to this decision the District Court of Appeals, in B. P. Schulberg Productions; Ltd. v. Employment Comm., $66 \mathrm{Cal}$. App. (2d) 831, 153 P. (2d) 404 (1944), observed that the legislature did not intend to incor- 
It is particularly notable that the attitude of the Connecticut and New York courts, although they were interpreting a statute without definitional aids other than a declaration of policy, seems to have been more effective in achieving results compatible with the purposes of the legislation than the "ABC" definition, with all its specificity of criteria, in the hands of less sympathetic courts. ${ }^{110}$ It seems safe to say that the Connecticut and New York courts, interpreting their respective statutes, would not have reached the same results as courts of other states in holding as a matter of law that employment relationships did not exist under the "ABC" definition. This seems to indicate that the success of specific statutory criteria of coverage depends ultimately upon the ability and willingness of judges to perceive new policy objectives of social legislation such as unemployment compensation laws, and to read the statutes in the light of those objectives.

\section{The Hearst Case}

The decision of the United States Supreme Court in National Labor Relations Board v. Hearst Publications, Inc.159 has very great significance for the interpretation of coverage provisions of unemployment compensation laws. The case involved the question whether the provisions of the National Labor Relations Act applied to newstoys who distributed daily papers of certain publishers on the streets of Los Angeles. The Act extends to "employees"; however, the content of the relationship thus characterized is not further defined in the Act or in the regulations of the National Labor Relations Board. The newsboys in question (who ". . are generally mature men," the Court observed ${ }^{121}$ ) sold papers at fixed places. The "profit" derived from their activities was the difference between the amount paid the companies for the papers, which could be a credit transaction, and the

porate into the unemployment compensation act the common law master-scruant concopt or the definitions contained in the workmen's compensation act, but provided spacifie definitions for unemployment compensation purposes. The court noted also that the act evidences "a legislative intent to give the words a broad and liberal description to the end that the far-reaching and evil effects of excessive unemployment may be eradieated." Id. at 835, 153 P. (2d) at 406. It remains to be seen whether the Supreme Court will give such substance to its view of liberal construction as to hold in "employment" parzons sho may ba servants under common-law criteria.

119. Thus the New York Court of Appeals in Matter of Satola, 282 X. Y. 659, 26 X. E. (2d) 815 (1910), held newscarriers to be in employment while the Washington Supreme Court in the Washington Recorder case held, under substantially the Eame facts, that as a nutter of law newscarriers were not in employment. And oddly, the Wyoming Supreme Court, in the Mathezs case, distinguished the "ABC" definition, which it restricted to common law rules, from the New York coverage provision by observing that "the New Yorl: law would appar to be considerably broader and more inclusive in its phraseology than the Wyoming law." 56 Wyo. 479, 495, 111 P. (2d) 111, 117 (1941).

120. 322 U. S. 111 (1941), reli'g denicd, 322 U. S. 769 (1944).

121. Id. at 116 . 
amount received from the customer, which was fixed by the publishers. The publishers furnished without charge certain equipment such as racks and money-change aprons. The Board found that the newsboys generally were required to be at the fixed spot from the time the papers customarily appeared on the streets to the time settlement was made, that in many instances newsboys had been transferred from one location to another, and that the diligence of the newsboys was closely observed by the publishers. On the review of the Board's order by the Court of Appeals for the Ninth Circuit, the Board argued that although the statute did not contain an elaboration of the term "employee," Congress contemplated a classification, larger than that envisioned by common law, that would include all persons who ". . . function in a realistic economic sense as employees of an industrial enterprise ...", and that the primary determinant should be "whether effectuation of the declared policy and purposes of the Act comprehend securing to the individual the rights guaranteed and protection afforded by the Act." ${ }^{122}$ The Court of Appeals, setting aside the Board order, concluded that if Congress had intended to enlarge upon the common-law meaning of "employee" it would have specifically so stated. ${ }^{123}$ The court pointed to the decision of the United States Supreme Court in Robinson v. Baltimore $\mathcal{E}^{\circ}$ Ohio Railroad Company that when Congress used the words "employee" and "employed" in the Federal Employer's Liability Act it intended to describe the "conventional relation of employer and employee." ${ }^{124}$ The basic inquiry, the court continued, is "where the right to control lies, and the control referred to must be complete control of the means and methods of performance." ${ }^{125}$ Considering the power of the publisher to terminate the relationship as simply the choice of a wholesaler not to continue sales to a retailer, the court found the newsboys to be vendees, and therefore independent contractors, and held them not to be "employees" as a matter of law.

This decision the Supreme Court reversed. In doing so, it penetrated to the heart of the matter by discussing, as the paramount issue, whether the term "employees" in the Wagner Act must be determined by reference to "common-law standards." Considering first the nature of the "common-law standards" the Court stated:

"The argument assumes that there is some simple, uniform and easily applicable test which the courts have used, in dealing with such problems, to determine whether persons doing work for others

122. Hearst Publications, Inc. v. National Labor Relations Board, 136 F. (2d) 608, 612 (C. C. A. 9th, 1943).

123. Ibid.

124. 237 U. S. 84, 94 (1915). The Robinson case was heavily relied upon by the Kentucky court in Barnes v. Indian Refining Co., $280 \mathrm{Ky} .811,134$ S. W. (2d) 620 (1939).

125. $136 \mathrm{~F} .(2 \mathrm{~d})$ at $612-3$. 
fall in one class or the other. Unfortunately this is not true. Only by a long and tortuous history was the simple formulation worked out which has been stated most frequently as 'the test' for deciding whether one who hires another is responsible in tort for his wrongdoing. But this formula has been by no means exclusively controlling in the solution of other problems. And its simplicity has been illusory because it is more largely simplicity of formulation than of application. Few problems in the law have given greater variety of application and conflict in results than the cases arising in the borderland between what is clearly an employer-employee relationship and what is clearly one of independent, entrepreneurial dealing. This is true within the limited field of determining vicarious liability in tort. It becomes more so when the field is expanded to include all of the possible applications of the distinction.

". . . It is enough to point out that, with reference to an identical problem, results may be contrary over a very considerable region of doubt in applying the distinction, depending upon the state or jurisdiction where the determination is made; and that within a single jurisdiction a person who, for instance, is held to be an 'independent contractor' for the purpose of imposing vicarious liability in tort may be an 'employee' for the purposes of particular legislation, such as unemployment compensation." $1 \mathrm{si}$

The Court concluded that any effort to apply "common-law standards" in administering the Wagner Act would necessitate reliance for decision either upon the law of each of the states with the numerous variations and distinctions developed therein for wholly different purposes, or "on a sort of pervading general essence distilled from state law." 1: The Court rejected both alternatives, the first because it would result in administering the statute ". . . in accordance with whatever different standards the respective states may see fit to adopt for the disposition of unrelated, local problems," 123 and the second because the administration of the statute might soon "become encumbered by the same sort of technical legal refinement as has characterized the long evolution of the employee-independent contractor dichotomy in the courts for other purposes."123 It concluded that whether the term "employee" in the Wagner Act includes particular persons "must be answered primarily from the history, terms and purposes of the legislation." 130 The Court found that "Congress had in mind a wider field

126. 322 U. S. at 120-2 (footnotes omitted), citing, by way of example, Globe Grain \& Milling Co. v. Industrial Comm., 9S Utah 36,91 P. (2d) 512 (1939), rel'g dericd, 98 Utah 48, 97 P. (2d) 582 (1939).

127. 322 U. S. at 122.

128. Id. at 123 .

129. Id. at 125 .

130. Id. at 124. However, the Supreme Court seemed to indicate, in discussing the findings of fact by the Board, that even under "common-law" criteria an employment relationship evisted. The Court observed that the publishers in a variety of vays preceribed, 
than the narrow technical legal relation of 'master and servant,' as the common law had worked this out in all its variations, and at the same time a narrower one than the entire area of rendering service to others." 131

To determine "how much was included of the intermediate region between what is clearly and unequivocally 'employment,' by any appropriate test, and what is as clearly entrepreneurial enterprise and not employment," ${ }^{132}$ the Court looked first to the Act's declaration of policy, which was to encourage collective bargaining:

"The mischief at which the Act is aimed and the remedies it offers are not confined exclusively to 'employees' within the traditional legal distinctions separating them from 'independent contractors.' Myriad forms of service relationship, with infinite and subtle variations in the terms of employment, blanket the nation's economy. Some are within this Act, others beyond its coverage. Large numbers will fall clearly on one side or on the other, by whatever test may be applied. But intermediate there will be many, the incidents of whose employment partake in part of the one group, in part of the other, in varying proportions of weight. And consequently the legal pendulum, for purposes of applying the statute, may swing one way or the other, depending upon the weight of this balance and its relation to the special purpose at hand.

"Unless the common-law tests are to be imported and made exclusively controlling, without regard to the statute's purposes, it cannot be irrelevant that the particular workers in these cases are subject, as a matter of economic fact, to the evils the statute was designed to eradicate and that the remedies it affords are appropriate for preventing them or curing their harmful effects in the special situation.". 133

The term "employee," the Court continued, "like other provisions, must be understood with reference to the purpose of the Act and the facts involved in the economic relationship. "Where all the conditions

if not the minutiae of daily activities, at least the broad terms and conditions of work, and that there were various "supervisory controls" by which the publisher's minimum standards of diligence and good conduct were enforced; and it concluded that, "However wide may be the latitude for individual initiative beyond those standards," supervisory instructions as to what were regarded as "helpful sales technique" were expected to be followed. It . at 110.

131. Id. at 124.

132. Id. at 124-5.

133. Id. at 126-7. Referring specifically to the traditional control test of the employment relationship found in the Restatement, the Court observed that the economic relationships which Congress thought it necessary to affect do not embrace only those in which controversies could be limited to disputes over proper "physical conduct in the performance of the service, "but that, on the contrary, "Congress recognized those economic relationships cannot be fitted neatly into the containers designated 'employee' and 'employer' which an earliet law had shaped for different purposes." Id. at 128. 
of the relation require protection, protection ought to be given.' " 134 The task of determining "where all the conditions of the relation require protection," said the Court, " "belongs to the usual administrative routine' of the Board," 135 so that a determination of the Board, as in the instant case, that specified persons are "employees" under the Act is to be accepted if it has warrant in the record and a reasonable basis in law.

The Hearst decision has this significance for the interpretation of unemployment compensation coverage provisions. First, it points up the ambiguity of the "common-law standards," a matter which seems to be so often ignored by courts which would appear to seek refuge from the necessity of imaginative inquiry into the development of unemployment compensation coverage criteria by attributing an assumed simplicity and certainty to those "standards." Second, the Court emphasizes the paramount importance of ascertaining the mischief which the legislation is designed to remedy and of interpreting the statutory definitions so as to achieve the legislative purpose. Thus, even in the event that terms which are used in the statute in question may also have been used in other statutes or at common lav for unrelated purposes (for example, the word "employee" in the Magner Act), primary reference need not be made to such other fields to find the content and scope of the terms, but rather to the history and policy objectives of the particular legislation. The opinion in these respects involves no departure from well-established legal principles, but their vigorous restatement and elaboration by the Supreme Court may vitalize the entire field of interpretation of coverage provisions in social legislation.

It may be hoped that the Hearst decision will have some influence upon courts which have appeared hostile or unsympathetic toward the "ABC" definition of employment. Clear recognition of the policy objectives implicit in unemployment compensation legislation (generally given expression in a "declaration of policy") and of the distinction between those objectives and others which may underlie the doctrine of respondeat superior, should lead courts to interpret the statutory criteria in harmony with the objectives of the unemployment compensation program. ${ }^{136}$ In the case of the Wagner Act the Court had no

134. Id. at 129 (footnote omitted), quoting from Lehigh Valley Cosl Co. v. Yensavage, 218 F. 547,552 (C. C. A. 2d, 1914).

135. Id. at 130 .

136. A clear grasp of the essential purposes of the legislation should preclude giving auch undue prominence to the contributions aspect of the program as to result in narrow and strict construction. See note 100 supra. See Grace v. Magruder, 143 F. (2d) 679 (App. D. C. 1915), involving the question whether the employment relationship existed with respact to "coal hustlers" for purposes of federal taxing provisions of the unemployment compansation and old-age and survivors' insurance programs; although these provisions are contained in the Internal Revenue Code (Chapter 9, subchapters A and C) separate, in the case of the 
difficulty in holding that "common-law standards" were inapplicable to the simple term "employee," and that restricting the definition to "common-law standards" would not do justice to the legislative intent. Certainly, in states which have the "ABC" definition, courts should have no difficulty in perceiving not only that there is a legislative intention to strike at an evil which has no necessary relation to the policy of the doctrine of respondeat superior, but that in the "ABC" definition criteria are prescribed for determining the employment relationship which are at variance with the common-law criteria and which are more clearly designed to facilitate effectuation of the purposes of the unemployment compensation program.

The Hearst decision has an equally clear import for those states whose laws do not contain the "ABC" definition, but which, like the Wagner Act, use more general terms. These statutes, too, have a history and generally contain declarations of policy to which the courts may refer to ascertain the legislative purpose. The Hearst case should influence courts, in interpreting these statutes, to disdain from attributing to the legislature the intention of adopting the "conventional" legal relationship of employer and employee and should lead to judicial interpretations which are consistent with the legislative objective.

old-age and survivors' insurance tax, from the benefit provisions of the program, the court concluded that the predominant purpose of the legislation is remedial, that the taxing provisions are but incidental, and therefore are to be construed liberally in favor of coverage. 